Accepted refereed manuscript of:

Eades C, Cameron D \& Evans J (2017) Prevalence of gestational diabetes mellitus in Europe: A meta-analysis, Diabetes Research and Clinical Practice, 129, pp. 173-181.

DOI: $\underline{10.1016 / j . d i a b r e s .2017 .03 .030}$

(C) 2017, Elsevier. Licensed under the Creative Commons Attribution-

NonCommercial-NoDerivatives 4.0 International

http://creativecommons.org/licenses/by-nc-nd/4.0/ 


\section{Prevalence of Gestational Diabetes Mellitus in Europe: A meta- analysis.}

Claire E Eades ${ }^{\mathrm{a}}$, Dawn M Cameron ${ }^{\mathrm{a}}$, Josie MM Evans ${ }^{\mathrm{a}}$,

${ }^{a}$ Faculty of Health Sciences and Sport, University of Stirling

Correspondence to:

Claire Eades

Faculty of Health Sciences and Sport, University of Stirling

Stirling

FK9 4LA

c.e.eades@stir.ac.uk

Tel: +44 [0] 1786466282

Fax: $+44[0] 1786466333$

Running title: Prevalence of gestational diabetes in Europe: A meta-analysis

Word Count Main Body: 4329

Word Count Abstract: 242 


\section{Abstract}

Aims: Estimates of the prevalence of gestational diabetes vary widely. It is important to have a clear understanding of the prevalence of this condition to be able to plan interventions and health care provision. This paper describes a meta-analysis of primary research data reporting the prevalence of gestational diabetes mellitus in the general pregnant population of developed countries in Europe.

Methods: Four electronic databases were systematically searched in May 2016. English language articles reporting gestational diabetes mellitus prevalence using universal screening in general pregnant population samples from developed countries in Europe were included. All papers identified by the search were screened by one author, and then half screened independently by a second author and half by a third author. Data were extracted by one author. Values for the measures of interest were combined using a random effects model and analysis of the effects of moderator variables was carried out.

Results: A total of 3258 abstracts were screened, with 40 studies included in the review. Overall prevalence of gestational diabetes mellitus was 5.4\% (3.8-7.8). Maternal age, year of data collection, country, area of Europe, week of gestation at testing, and diagnostic criteria were found to have a significant univariate effect on GDM prevalence, and area, week of gestation at testing and year of data collection remained statistically significant in multivariate analysis. Quality category was significant in multivariate but not univariate analysis.

Conclusions: This meta-analysis shows prevalence of GDM that is at the upper end of previous estimates in Europe.

Keywords: Gestational diabetes mellitus; Prevalence; Europe; Meta-analysis. 


\section{Introduction}

Gestational Diabetes Mellitus (GDM) is defined as glucose intolerance that is first diagnosed in pregnancy and increases the risk of complications for both mother and baby during pregnancy [1]. It is estimated that GDM affects around 7\% of all pregnancies worldwide although prevalence is difficult to estimate as rates vary from study to study because of a lack of accepted diagnostic criteria and differences in screening procedures [2]. Some earlier diagnostic criteria were based on the criteria used in non-pregnant individuals and in others thresholds were created based on the predictive value of future type 2 diabetes in the mother. In recent years, there has been an increasing focus on diagnostic thresholds that predict the likelihood of adverse outcomes in pregnancy (HAPO) [3]. Adverse outcomes include macrosomia, shoulder dystocia and birth injury, primary caesarean delivery, preeclampsia, preterm delivery and foetal and neonatal mortality [4].

In addition to adverse outcomes during pregnancy and birth, the consequences of GDM extend beyond pregnancy with affected women having a seven fold increased risk of type 2 diabetes mellitus compared to women who have not had GDM. Rates of type 2 diabetes mellitus after a diagnosis of GDM vary depending on the population and length of follow up, but have been reported to be as high as $70 \%[5 ; 6]$. Women are thought to be at the greatest risk of developing type 2 diabetes mellitus in the first five years following a pregnancy with GDM, with incidence of type 2 diabetes mellitus plateauing at around 10 years [6].

Although women who have had GDM are at an increased risk of type 2 diabetes mellitus, research has shown that by making lifestyle changes they can prevent or delay progression to type 2 diabetes mellitus [7]. With prevalence of type 2 diabetes mellitus increasing rapidly, a diagnosis of GDM represents an opportunity for intervention to reduce the burden of type 2 diabetes mellitus [8]. This is why it is so important to have a full and clear understanding of the prevalence of this condition in order to be able to plan such interventions and health care provision. We have therefore conducted a meta-analysis of observational primary research studies that have assessed the prevalence of GDM in the general population of pregnant women in developed countries in Europe, regardless of the specific diagnostic criteria used. We have derived an overall prevalence estimate for GDM and examined 
moderator variables that potentially influenced this estimate. Although narrative reviews exist on this topic, this is the first systematic review and meta-analysis to bring together and synthesise all the evidence.

\section{Material and Methods}

\subsection{Literature search and study selection}

A meta-analysis of primary research studies reporting prevalence of GDM was undertaken in accordance with the Meta-analysis of Observational Studies in Epidemiology (MOOSE) guidelines for reviews [9]. A search was conducted in MEDLINE, CINAHL, Health Source and PsycInfo for articles published before June 2016. The following combination of search terms were used with each database: (prevalence or incidence) and (gestational diabetes or diabetes in pregnancy or gestational diabetes mellitus). Reference lists and citations of included papers were checked to identify any other potentially relevant papers but key authors and experts in the field were not contacted due to the time consuming nature of this process with no guarantee of obtaining relevant information.

After removing duplicates, the title and abstract of all papers were screened by one author (CE). Independent screening of records was split between the two other authors, with JE screening half and DC screening the other half. The full texts of papers were retrieved for studies that were considered relevant, but also for those that contained insufficient information to allow judgement of relevance. These were checked against the inclusion criteria by CE and independently by JE. Reference lists of included articles were reviewed to identify any additional relevant articles. In cases of disagreement between authors about the inclusion of a paper, the full text of the paper was accessed and consensus was reached through discussion.

Papers were screened against the following inclusion criteria:

1) Population: general population of pregnant women, living in a developed country in Europe (as defined by the Financial Times Stock Exchange). 
2) Outcome measure: prevalence of GDM diagnosed using universal screening carried out in the second or third trimester, using either a GTT alone or two step screening with glucose challenge test (GCT) followed by a GTT.

3) Study design: observational study, published in English.

The review was limited to developed countries in Europe because of the wide differences in prevalence of type 2 diabetes mellitus and GDM between developed and developing countries $[5,10]$. This removed one potential source of heterogeneity in the review and also ensured its relevance for informing care and development of interventions in the context of developed health care systems. Studies were defined as having a sample drawn from the general population of pregnant women if it was drawn from a source that covered the majority of the population, such as population registers, general practice registers or registers of clinics for pregnant women (in countries where registration at general practices and clinics for pregnancy women is near to universal). If this information was not reported, studies were only included if the paper explicitly stated that the sample was drawn from a general population. Studies that selected people who were at high risk of GDM (due to family history of type 2 diabetes mellitus, or lifestyle and medical factors) were excluded. Studies were excluded if the majority of the sample were immigrants and did not originate from an included developed country.

\subsection{Data extraction and coding}

Data were extracted and summarised from potentially relevant studies by one author (CE) using a standardised data extraction form based on the example provided by the Centre for Reviews and Dissemination [11]. Confidence intervals were calculated where possible for studies that did not report these for prevalence figures. Where there were multiple papers published that were based upon the same sample, only the paper reporting the most complete and definitive results was included. However, more than one paper from the same sample was included in the review if each paper reported on a unique aspect of the findings. 
The following information was extracted from each included study: first author, journal name and year of publication, country of study population, study period, study sample type, study design, age range, response rate, sample size, type of screening/testing carried out and diagnostic criteria for GDM. The outcome measures extracted were number and proportion of sample with GDM, and where reported the number and proportion of sample with GDM by different demographic factors such as age and Body Mass Index (BMI).

Where individual studies reported multiple prevalence estimates according to different diagnostic criteria, only one prevalence estimate was included in the meta-analysis to avoid dependency effects. The prevalence estimate deriving from the criteria that were most commonly used in other papers in the review was the one selected for inclusion in the meta-analysis so that the estimate would be comparable to other studies in the review. For studies reporting multiple prevalence estimates by other factors, such as age or year, an average of the estimates was calculated and used in the analysis.

\subsection{Quality appraisal}

The quality of included studies was assessed using a checklist based upon the example published by the Joanna Briggs Institute [12] which was designed for assessment of quality in systematic reviews of prevalence and incidence. Quality assessment was completed for all included papers by one author (CE) and a list of all identified weaknesses was compiled. The list was then discussed by all of the authors and the weaknesses were categorised as high, medium or low according to how likely they were to put the study at risk of bias. High risk weaknesses were those that put the study at high risk of bias or made the risk of bias difficult to assess, and included not reporting participation rate, very low participation rate $(<50 \%)$ or not reporting the source of the study sample (e.g. census, general practice register). Participation rates can be defined in many ways but for this review the participation rate (recoded during data extraction if necessary and possible) was the proportion of eligible people sampled who completed testing for GDM. Medium risk weaknesses included low participation rate (50-70\%), not reporting women's gestation at testing and sample size of less than 300. Low risk 
weaknesses included not reporting characteristics of the sample and not reporting differences between participants and non-participants.

Included studies were then given a quality rating as follows:

1: Only low risk weaknesses

2: One medium or more than one low risk weakness.

3: One high risk or multiple medium risk weaknesses.

\subsection{Data Analysis}

The meta-analysis was carried out using the Comprehensive Meta-Analysis software version 3.3.070 (Biostat, Englewood, NJ). For each study, the proportion of people with GDM was transformed into a logit event rate effect size and the standard error associated with this was calculated [13]. The logits were retransformed to proportions after analysis to aid interpretation of the results. Combined effect sizes were calculated and analyses were carried out twice: both including and excluding outlying logit event rates. No significant differences were found between these analyses so outliers were retained in the analyses.

Significance tests and moderator analysis were carried out using a random effects model. Fixed effects models make the assumption that the effect size observed in a study estimates the corresponding population effect with random error that comes only from the chance factors associated with subject level sampling error [13]. In contrast, random effects models allow for the possibility that there are also random differences between studies that are not only due to sampling error but as a result of some other factor such as variation in procedures, measures or settings. The choice of the random effects model to combine studies in this meta-analysis was based upon literature on GDM prevalence which suggests that the variability in reported prevalence for GDM may be the result of the use of different methodologies and criteria [5]. 
The homogeneity of studies was evaluated using the $\mathrm{Q}$ test where the null hypothesis states that variability of the effect sizes is the result of sampling error only. If the assumption of homogeneity is violated it is customary for sources of variation to be explored by studying moderator variables. Q and $\mathrm{I}^{2}$ statistics were also calculated to assess differences in combined effect sizes for sets of studies grouped according to moderator variables.

Categorical moderator variables were analysed using an analysis of variance for meta-analysis. Differences between subgroups of these variables were explored using a test of interaction. The between study homogeneity statistic $\left(\mathrm{Q}_{\mathrm{B}}\right)$ reflects the amount of heterogeneity that can be attributed to the moderator variable. The within study homogeneity statistic indicates the degree of heterogeneity that remains in the category in question $\left(\mathrm{Q}_{\mathrm{W}}\right)$ and the $\mathrm{I}^{2}$ statistic shows the proportion of the variation that is due to heterogeneity rather than sampling error. For continuous variables, a simple weighted regression was used, where $\mathrm{Q}_{\mathrm{R}}$ represents the proportion of variability associated with the regression model and $\mathrm{Q}_{\mathrm{E}}$ indicates the variability unaccounted for by the model.

\section{Results}

\subsection{Description of Included Studies}

Figure 1 shows a PRISMA flow diagram of studies identified by the search. The search identified 3,258 abstracts of which 161 were potentially relevant after title and abstract screening. The full text articles were retrieved and assessed against the inclusion criteria, resulting in 40 included studies reported in 41 papers [14-53] (additional papers: [54]). These 40 studies included a total of 1,778,399

participants. The characteristics of the studies included in the review are presented in Table 1. Studies were conducted across 11 of the 17 countries defined as developed European countries: Italy $(n=9)$, Sweden ( $n=7)$, Spain ( $n=7)$, France $(n=4)$, UK ( $n=5)$, Ireland $(n=2)$, Belgium $(n=2)$, Greece $(n=1)$, Finland $(\mathrm{n}=1)$, Austria $(\mathrm{n}=1)$, and Switzerland $(\mathrm{n}=1)$. No additional papers were identified by manual searching of reference lists.

Around half of studies $(\mathrm{n}=22)$ used a single step screening strategy where all women were given a GTT, and the others used two-step screening, where all women were screened first with a GCT, then 
those with a positive GCT were given a GTT. Two studies used both one-step screening in one cohort, and two-step screening in a second separate cohort of women [28,53]. The most commonly used diagnostic criteria were Carpenter and Coustan [55] which were used to diagnose GDM in 14 studies as part of two-step screening and one study using one-step screening. The IADPSG criteria [56] were applied in a total of ten studies, of which nine used one-step screening and one used two-step screening. The NDDG [57] criteria were used in three studies using two-step screening and one study using one-step screening. A modification of the EASD criteria [58] that diagnosed GDM on the basis of two hour values only without assessing fasting blood glucose was used in four studies all using one step screening. Only three studies reported that they tested for and excluded any women with undiagnosed pre-existing diabetes that was uncovered in the first trimester.

\subsection{Quality of Studies}

The quality category assigned to each study is reported in Table 1 . Three studies were identified that had two major weaknesses [59-61]: in all three studies it was not clear if the study sample was a whole population of pregnant women and response rates were not reported. These studies were excluded from the review as this particular combination of problems made it difficult to assess the risk of bias in the study. The majority of included studies were classed as either the higher $(n=23)$ or middle quality category $(n=11)$ and therefore had only low or medium risk weaknesses. The remaining studies fell in to the lower quality category $(n=6)$ and in addition to any low risk weaknesses also had weaknesses that put the study at higher risk of bias. These higher risk weaknesses included non-reporting of response rate $(n=4)$, not reporting where women were recruited from $(n=1)$ and very low participation rate $(n=1)$. Of the weaknesses categorised as low or medium risk, the most common problems were non-reporting of sample characteristics $(n=21)$, non-reporting of information on women who did not participate $(n=17)$, low participation rate $(n=5)$, and nonreporting of gestation at testing $(n=2)$.

\subsection{Analysis of Outliers}

One outlier was identified that reported prevalence of $35.5 \%$ [28]. This figure was reported for a cohort of women with a median age of 32 and median pre-pregnancy BMI of $22.8 \mathrm{~kg} / \mathrm{m}^{2}$ and who were 
diagnosed with GDM through universal screening using IADSPG criteria. The majority of women were Caucasian (62\%) and only $2 \%$ had previous GDM. These characteristics are largely similar to those of other studies giving no clear explanation for the high prevalence found in this study.

\subsection{Mean Prevalence of GDM}

The mean prevalence of GDM overall was 5.4\% (95\% CI: 3.8-7.8). The mean prevalence in studies using one-step screening was $6.4 \%(3.8-10.4)$ and $4.7 \%(2.7-8.1)$ in studies using two-step screening. There was no significant difference in prevalence of GDM between studies using one-step and twostep screening $\left(\mathrm{Q}_{[1]}=0.64 ; \mathrm{p}=0.424\right)$. The analysis of homogeneity in the data with regards to type of screening showed variability within studies assessing prevalence using one-step screening $\left(\mathrm{Q}_{[19]}=13019.04 ; \mathrm{p}<0.001\right)$ and those using two-step screening $\left(\mathrm{Q}_{[21]}=15517.54 ; \mathrm{p}<0.001\right)$.

\subsection{Analysis of Moderators for GDM}

As there was no significant difference in prevalence of GDM by screening type, the analysis of prevalence by moderator variables is presented in overall terms. Table 2 shows the individual effects of different categorical moderator variables. Sample age, diagnostic criteria, country the study was conducted in, year that data collection started and week of gestation at testing, all had a significant effect on the prevalence of GDM, whereas the quality category of studies, mean BMI, ethnicity, and family history of diabetes in samples, did not have a significant effect. There were too few studies reporting parity data for this variable to be included in analyses.

\subsubsection{Sample Age}

Prevalence was higher in samples with a mean age of 30.8 years and over $(9.6 \% ; 6.7-13.7)$ compared to those with a mean age of 30.7 and under $(4.3 \% ; 2.3-8.0)$.

\subsubsection{Diagnostic Criteria}

Analysis of the effect of diagnostic criteria on GDM prevalence found the highest prevalence estimate in studies using the IADPSG criteria (14.1\%; 9-21.5; [56]), the second highest prevalence was found in studies using Carpenter and Coustan criteria (6.9\%; 5.4-8.7; [55]). The second lowest prevalence estimate was in studies using the NDDG criteria $(5.3 \%$; $2.7-10 ;[62])$ and the lowest estimate was for those that defined GDM using modified EASD criteria with two hour readings only (1.4\%; 0.9-2.2). 


\subsubsection{Country}

In the analysis by country, the highest prevalence was found in studies conducted in Italy $(10 \%$; $7.6-$ 13) and the lowest in Sweden (1.5\%; 1-2.3). Countries were sorted into three groups according to location in Europe: Northern Europe, Western Europe, Southern Europe. Highest prevalence was found in countries in Southern Europe $(9.6 \% ; 7.3-12.6)$ and lowest in Northern Europe $(2.3 \%$; $1.3-$ $3.8)$.

\subsubsection{Year}

Estimates of GDM prevalence increased every decade with the lowest in the 1980s [0.9\%; 0.1-10] and the highest in the 2010s (11.1\%; 5.7-20.6).

\subsubsection{Gestation at testing}

The highest prevalence estimate for GDM was found in studies that screened for GDM at multiple time points in the second and third trimester $(13.1 \%$; $6.5-24.7)$ followed by those studies that tested participants between 24 and 28 weeks of gestation $(7.5 \% ; 5.9-9.4)$. The lowest prevalence estimate was in a study that screened for GDM at 28 to 32 weeks gestation $(1.7 \% ; 1.3-2.2)$. However, as this category only contained a single study this result must be interpreted with caution. The second lowest prevalence estimate was found in studies that screened only at 28 weeks of gestation $(1.9 \% ; 1.5-2.5)$.

\subsubsection{Multivariate analysis}

A weighted multiple regression was performed in order to explore which variables made the greatest contribution to the variability in prevalence of GDM. All variables explored in the univariate analysis were initially entered into the model except for sample age and mean BMI as there were too few studies reporting these variables for them to be included in the multivariate analysis. Correlations between different variables were explored and used to inform the selection of variables for the multiple regression. A moderate correlation was found between year of data collection and diagnostic criteria $(\mathrm{r}=0.478 ; \mathrm{p}=0.010 ; \mathrm{n}=28)$. The variable diagnostic criteria could not be included in the multiple regression because of collinearity with this and other variables.

The final model included the following variables: quality category, type of screening (one or two step), gestation at testing, year data collection started and area of Europe. These variables accounted for $83 \%$ of total observed variability $\left(\mathrm{Q}_{\mathrm{R}[11]}=125.6, \mathrm{p}<0.001\right.$, see Table 3 for full results $)$. All three of 
the variables that were significant in univariate analyses [area, gestation at testing and year of data collection] remained statistically significant when the other variables were held constant. Quality category and type of screening were not significant in univariate analysis but were significant in the multiple regression. However, the residual model was also statistically significant $\left(\mathrm{Q}_{\mathrm{E}[23]}=1134.95\right.$; $\left.\mathrm{p}<0.001, \mathrm{I}^{2}=98.0 \%\right)$ meaning that there was still variability in the data that was not explained by the variables analysed.

\section{Discussion}

This meta-analysis of 1,770,63 participants in 40 studies reported mean prevalence of GDM of 5.4\%. No differences were found in prevalence estimates of GDM according to the type of screening used (one-step or two-step), mean BMI, ethnicity and family history. An increase in prevalence was found with increasing sample age and year of data collection. Diagnostic criteria, country and week of gestation at testing were also found to have an effect on GDM prevalence. Nevertheless, given the changing migration patterns across Europe, this prevalence estimate may well change in the future.

The study methods were systematic and robust. We used independent reviewers to screen all of the titles and abstracts identified by the search for inclusion in the review. All decisions on the inclusion of papers were discussed and agreed upon by all three authors. A thorough quality assessment was conducted for all studies considered for inclusion using a template designed for observational epidemiology studies and the majority of studies included were of high quality. The methodology had only minor limitations: only papers published in the English language were included, experts in the field were not contacted, grey literature was not identified and data extraction was only carried out by one author.

The quality assessment ensured that the majority of studies included in the review had relatively good participation rates and recruited participants from sources with coverage of the majority of the pregnant population (e.g. clinic register) using appropriate methods (e.g. whole population). The majority of included studies had good participation rates. Only four studies had participation rates of 
50 to $70 \%$ and only one study had a very low participation rate of less than $50 \%$. This allows us to be reasonably confident that the included studies used samples that were representative of the general pregnant population. Quality category of the study was not found to have any significant effect on prevalence of GDM in univariate analysis but was significant in the multiple regression.

Non-reporting of various methodological details was a common problem which made it difficult to assess fully the quality of some studies. However, the impact of this problem on the quality of the review was minimised by the decision to exclude any studies that had more than one weakness defined by the authors as major. Collating data on GDM prevalence was also made difficult by heterogeneity in approaches to sampling, methods used to collect blood samples and the criteria used to define GDM.

The way GDM is defined makes it difficult to differentiate between pre-existing undiagnosed diabetes and GDM. The IADPSG guidelines suggest that all women or those at high risk have either fasting blood glucose, A1c or random blood glucose measured at the first prenatal visit and overt diabetes diagnosed if fasting blood glucose is $126 \mathrm{mg} / \mathrm{dl}$ or higher or A1c $6.5 \%$ or higher [56]. Only three of the studies included in the present review reported that they tested for pre-existing undiagnosed diabetes in this way and excluded any women meeting the criteria. Of these three studies two reported the number of women thus identified and in both the prevalence was very low at $0.1 \%$ and $0.5 \%$. Similarly, analysis of the national health and nutrition examination survey carried out between 1999 and 2010 in the United States showed that approximately $0.5 \%$ of women of non-pregnant women of reproductive age had undiagnosed diabetes [63]. Therefore, although estimates of GDM may be inflated by the potential inclusion of women with undiagnosed pre-existing diabetes, given the low prevalence of this it is unlikely that the effect on GDM estimates would be large.

The ADA guidelines estimate that around 7\% of pregnant women will be diagnosed with GDM [2] and a review by of GDM prevalence in Europe reported rates of between 2 and 6\% [1]. This estimate of 2-6\% was based on studies using both risk-based and universal screening, whereas our estimate of 
5\% was based only upon studies using universal screening which identifies more women with GDM than risk-based screening [16,42].

The specific diagnostic criteria was found to have a significant effect on prevalence estimates in this review, with the IADPSG [56] criteria giving the highest estimates and a modified EASD [58] and Carpenter Coustan [55] giving the lowest estimates. In contrast, the review by Buckley et al. $[1 ; 63)$ reported no consistent trend in prevalence according to diagnostic criteria. The IADPSG criteria were proposed on the basis of evidence from the HAPO study on the relationship between maternal hyperglycaemia and adverse outcomes. A number of associations, including the ADA, have adopted these recommendations while others have argued that they will increase prevalence without necessarily improving outcomes. A study by Duran et al [26] has since shown that while using the IADPSG criteria does increases GDM prevalence, it also result in significant improvements in pregnancy outcomes . This study reported increases in prevalence of 3.5 times compared to Carpenter and Coustan criteria whereas we found rates according to IADPSG criteria to be around double Carpenter and Coustan.

The present review confirmed previous research showing that GDM prevalence increases with increasing maternal age and is higher in Southern and Western Europe compared to Northern Europe [1]. We did not find any effect for BMI, ethnicity or family history, but there were few studies that measured or reported these variables so there may have been insufficient power to detect any differences. A strength of the present study is that pooling studies using meta-analysis allows trends to be identified when there are inconsistencies between individual studies.

With GDM being closely linked to type 2 diabetes mellitus and sharing some risk factors, we would expect to see an increase in GDM over time [1]. Although we found significant increases in GDM prevalence over time, year of data collection was moderately correlated with diagnostic criteria. The IADPSG criteria were associated with the highest prevalence estimates for GDM but were also the criteria published most recently. It was not possible to enter diagnostic criteria in to the multivariate analysis which makes it difficult to assess how much of the increase in prevalence over time was 
related to the widening of diagnostic criteria and how much it reflected true increases in prevalence. Increases in screening over time also makes interpreting trend in prevalence difficult [64], although by including only studies using universal screening this source of heterogeneity was removed from this review.

In summary, this is the first meta-analysis to bring together all the relevant evidence relating to GDM prevalence in Europe and to make sense of disparate findings. In the general population of developed Europe, around 1 in 20 pregnant women meet the criteria for GDM. These figures provide a basis for the planning of interventions and health care provision for the prevention of type 2 diabetes mellitus. We now recommend that similar meta-analyses be conducted in other populations for comparison, for example those from developing countries, and from North America and Asia.

\section{Funding}

Funding to undertake this review was provided by the Faculty of Health Sciences and Sport, University of Stirling.

\section{Duality of Interest}

None declared.

\section{Contribution to Authorship}

CE designed the study, assisted with screening of data, conducted data extraction, performed analyses and drafted the manuscript. JE assisted with screening papers, analyses and drafting the manuscript. DC assisted with screening papers, analyses and drafting the manuscript. 


\section{References}

[1] Buckley BS, Harreiter J, Damm P, Corcoy R, Chico A, Simmons D, et al. Gestational diabetes mellitus in Europe: prevalence, current screening practice and barriers to screening. A review.

Diabetic Med 2012;29[7]:844-854.

[2] Gestational Diabetes Mellitus. Diabetes Care 2003 American Diabetes Association;26[suppl $1]:$ s103-s105.

[3] Hadar E, Oats J, Hod M. Towards new diagnostic criteria for diagnosing GDM - the HAPO study. J Perinat Med 2009;37[5]:447-449 3p.

[4] Yogev Y, Visser GHA. Obesity, gestational diabetes and pregnancy outcome. Semin Fetal Neonatal Med 2009;14[2]:77-84.

[5] Ferrara A. Increasing prevalence of gestational diabetes mellitus: a public health perspective. Diabetes Care 2007;30:S141-6 1p.

[6] Kim C, Newton KM, Knopp RH. Gestational Diabetes and the Incidence of Type 2 Diabetes. Diabetes Care 2002;25[10]:1862-1868.

[7] Unwin N, Shaw J, Zimmet P, Alberti KGMM. Impaired glucose tolerance and impaired fasting glycaemia: the current status on definition and intervention. Diabet Med 2002;19[9]:708-723.

[8] Davies MJ, Tringham JR, Troughton J, Khunti KK. Prevention of Type 2 diabetes mellitus. A review of the evidence and its application in a UK setting. Diabetic Med 2004;21 [5]:403-414.

[9] Stroup D, Berlin J, Morton S, Olkin I, Williams G, Rennie D, et al. Meta-analysis of observational studies in epidemiology. A proposal for reporting. Journal of the American Medical Association 2000;283[15]:2008-2012.

[10] Wild S, Roglic G, Green A, Sicree R, King H. Global Prevalence of Diabetes. Diabetes Care 2004;27[5]:1047-1053.

[11] Centre for Reviews and Dissemination. Systematic Reviews. CRD's guidance for undertaking reviews in healthcare. 2009.

[12] Joanna Briggs Institute. The Joanna Briggs Institute reviewer's manual 2014. The systematic review of prevalence and incidence data. 2014.

[13] Lipsey MW, Wilson DB. Practical meta-analysis. California: Sage Publications; 2000.

[14] Åberg A, Rydhstroem H, Frid A. Impaired glucose tolerance associated with adverse pregnancy outcome: A population-based study in southern Sweden. American Journal of Obstetrics \& Gynecology 2001;184[2]:77-83.

[15] Alberico S, Strazzanti C, De Santo D, De Seta F, Lenardon P, Bernardon M, et al. Gestational diabetes: universal or selective screening? J Matern Fetal Neonatal Med 2004;16[6]:331-337.

[16] Anderberg E, Källén K, Berntorp K, Frid A, Aberg A. A simplified oral glucose tolerance test in pregnancy: compliance and results. Acta Obstet Gynecol Scand 2007;86[12]:1432-1436. 
[17] Avalos GE, Owens LA, Dunne F. Applying current screening tools for gestational diabetes mellitus to a European population: is it time for change? Diabetes Care 2013;36[10]:3040-3044.

[18] Breschi MC, Seghieri G, Bartolomei G, Gironi A, Baldi S, Ferrannini E. Relation of birthweight to maternal plasma glucose and insulin concentrations during normal pregnancy. Diabetologia $1993 ; 36[12]: 1315-1321$.

[19] Bugallo FM, Alvarez CR, Aguirre-Jaime A, Di Renzo GC, Gonzalez NL. Effectiveness of a screening protocol for gestational diabetes in pregnant Spanish women. J Matern Fetal Neonatal Med 2011;24[7]:917-922.

[20] Cauza E, Hanusch-Enserer U, Bischof M, Spak M, Kostner K, Tammaa A, et al. Increased C282Y heterozygosity in gestational diabetes. Fetal Diagn Ther 2005;20[5]:349-354.

[21] Chevalier N, Fénichel P, Giaume V, Loizeau S, Bongain A, Daideri G, et al. Universal two-step screening strategy for gestational diabetes has weak relevance in French Mediterranean women: should we simplify the screening strategy for gestational diabetes in France? Diabetes Metab 2011;37[5]:419-425.

[22] Chico A, Lopez-Rodo V, Rodriguez-Vaca D, Novials A. Features and outcome of pregnancies complicated by impaired glucose tolerance and gestational diabetes diagnosed using different criteria in a Spanish population. Diabetes Res Clin Pract 2005;68[2]:141-146 6p.

[23] Coolen JCG, Verhaeghe J. Physiology and clinical value of glycosuria after a glucose challenge during pregnancy. Eur J Obstet Gynecol Reprod Biol 2010;150[2]:132-136.

[24] Cordero Y, Mottola MF, Vargas J, Blanco M, Barakat R. Exercise Is Associated with a Reduction in Gestational Diabetes Mellitus. Med Sci Sports Exerc 2015;47[7]:1328-1333.

[25] Corrado F, D'Anna R, Cannata ML, Interdonato ML, Pintaudi B, Di Benedetto A.

Correspondence between first-trimester fasting glycaemia, and oral glucose tolerance test in gestational diabetes diagnosis. Diabetes Metab 2012;38[5]:458-461.

[26] Cosson E, Benchimol M, Carbillon L, Pharisien I, Pariès J, Valensi P, et al. Universal rather than selective screening for gestational diabetes mellitus may improve fetal outcomes. Diabetes Metab 2006;32[2]:140-146.

[27] Di Cianni G, Volpe L, Lencioni C, Miccoli R, Cuccuru I, Ghio A, et al. Prevalence and risk factors for gestational diabetes assessed by universal screening. Diabetes Res Clin Pract 2003;62[2]:131-137.

[28] Duran A, Sáenz S, Torrejón MJ, Bordiú E, Valle Ld, Galindo M, et al. Introduction of IADPSG Criteria for the Screening and Diagnosis of Gestational Diabetes Mellitus Results in Improved Pregnancy Outcomes at a Lower Cost in a Large Cohort of Pregnant Women: The St. Carlos Gestational Diabetes Study. Diabetes Care 2014;37[9]:2442-2450.

[29] Fadl HE, Ostlund IKM, Magnuson AFK, Hanson USB. Maternal and neonatal outcomes and time trends of gestational diabetes mellitus in Sweden from 1991 to 2003. Diabet Med 2010;27[4]:436-441.

[30] Fedele D, Lapolla A. A protocol of screening of gestational diabetes mellitus. Ann Ist Super Sanita 1997;33[3]:383-387. 
[31] Griffin ME, Coffey M, Johnson H, Scanlon P, Foley M, Stronge J, et al. Universal vs. risk factorbased screening for gestational diabetes mellitus: detection rates, gestation at diagnosis and outcome. Diabetic Med 2000;17[1]:26-32.

[32] Ignell C, Claesson R, Anderberg E, Berntorp K. Trends in the prevalence of gestational diabetes mellitus in southern Sweden, 2003-2012. Acta Obstet Gynecol Scand 2014;93[4]:420-424.

[33] Janghorbani M, Stenhouse EA, Jones RB, Millward BA. Is neighbourhood deprivation a risk factor for gestational diabetes mellitus? Diabet Med 2006;23[3]:313-317.

[34] Jiménez-Moleón J,J., Bueno-Cavanillas A, Luna-Del-Castillo J,D., Garciá-Martín M, LardelliClaret P, Gálvez-Vargas R. Prevalence of gestational diabetes mellitus: variations related to screening strategy used. Eur J Endocrinol 2002;146[6]:831-837.

[35] Lacaria E, Lencioni C, Russo L, Romano M, Lemmi P, Battini L, et al. Selective screening for GDM in Italy: application and effectiveness of National Guidelines. J Matern Fetal Neonatal Med 2015;28[15]:1842-1844.

[36] Lind T, Anderson J. Does random blood glucose sampling outdate testing for glycosuria in the detection of diabetes during pregnancy? British Medical Journal [Clinical Research Edition] 1984 ;289[6458]:1569-1571.

[37] Lindqvist M, Persson M, Lindkvist M, Mogren I. No consensus on gestational diabetes mellitus screening regimes in Sweden: pregnancy outcomes in relation to different screening regimes 2011 to 2012, a cross-sectional study. BMC Pregnancy Childbirth 2014;14:185-185.

[38] Malmqvist E, Jakobsson K, Tinnerberg H, Rignell-Hydbom A, Rylander L. Gestational Diabetes and Preeclampsia in Association with Air Pollution at Levels below Current Air Quality Guidelines. Environ Health Perspect 2013;121[4]:488-493.

[39] Meek CL, Lewis HB, Patient C, Murphy HR, Simmons D. Diagnosis of gestational diabetes mellitus: falling through the net. Diabetologia 2015;58[9]:2003-2012.

[40] Miailhe G, Kayem G, Girard G, Legardeur H, Mandelbrot L. Selective rather than universal screening for gestational diabetes mellitus? Eur J Obstet Gynecol Reprod Biol 2015;191:95-100.

[41] Orecchio A, Periard D, Kashef A, Magnin J, Hayoz D, Fontana E. Incidence of gestational diabetes and birth complications in Switzerland: screening in 1042 pregnancies. Gynecol Endocrinol 2014;30[8]:561-564.

[42] Ostlund I, Hanson U. Occurrence of gestational diabetes mellitus and the value of different screening indicators for the oral glucose tolerance test. Acta Obstet Gynecol Scand $2003 ; 82[2]$ :103108.

[43] Pérez-Ferre N, Fernández D, Torrejón M,J., Del Prado N, Runkle I, Rubio MA, et al. Effect of lifestyle on the risk of gestational diabetes and obstetric outcomes in immigrant Hispanic women living in Spain. J Diabetes 2012;4[4]:432-438.

[44] Pintaudi B, Di Vieste G, Corrado F, Lucisano G, Pellegrini F, Giunta L, et al. Improvement of selective screening strategy for gestational diabetes through a more accurate definition of high-risk groups. Eur J Endocrinol 2013;170[1]:87-93. 
[45] Pöyhönen-Alho M,K., Teramo KA, Kaaja RJ, Hiilesmaa VK. 50gram Oral Glucose Challenge Test Combined with Risk Factor-Based Screening for Gestational Diabetes. Eur J Obstet Gynecol Reprod Biol 2005;121[1]:34-37.

[46] Ricart W, López J, Mozas J, Pericot A, Sancho MA, González N, et al. Potential impact of American Diabetes Association [2000] criteria for diagnosis of gestational diabetes mellitus in Spain. Diabetologia 2005;48[6]:1135-1141.

[47] Ryser Rüetschi J, Jornayvaz FR, Rivest R, Huhn EA, Irion O, Boulvain M. Fasting glycaemia to simplify screening for gestational diabetes. BJOG 2016 01/25.

[48] Sommer C, Jenum AK, Waage CW, Mørkrid K, Sletner L, Birkeland K. Ethnic differences in BMI, subcutaneous fat, and serum leptin levels during and after pregnancy and risk of gestational diabetes. Eur J Endocrinol 2015;172[6]:649-656.

[49] Vassilaki M, Chatzi L, Georgiou V, Philalithis A, Kritsotakis G, Koutis A, et al. Pregestational excess weight, maternal obstetric complications and mode of delivery in the Rhea cohort in Crete. Eur J Public Health 2015;25[4]:632-637.

[50] Vignoles P, Gire C, Mancini J, Bretelle F, Boubli L, Janky E, et al. Gestational diabetes: a strong independent risk factor for severe neonatal respiratory failure after 34 weeks. Arch Gynecol Obstet 2011;284[5]:1099-1104.

[51] Sacks, D, Hadden, D, Maresh, M, Deerochanawong, C, Dyer, A, Metzger, B, et al. Frequency of Gestational Diabetes Mellitus at Collaborating Centers Based on IADPSG Consensus PanelRecommended Criteria. Diabetes Care 2012; 35 (3): 526-528.

[52] Murgia C, Berria R, Minerba L, Sulis S, Murenu M, Portoghese E, et al. Risk assessment does not explain high prevalence of gestational diabetes mellitus in a large group of Sardinian women. Reprod Biol Endocrinol 2008;6:26-26.

[53] O'Sullivan,E.P., Avalos G, O'Reilly M, Dennedy MC, Gaffney G, Dunne F. Atlantic Diabetes in Pregnancy [DIP]: the prevalence and outcomes of gestational diabetes mellitus using new diagnostic criteria. Diabetologia 2011;54[7]:1670-1675.

[54] Oriot P, Selvais P, Radikov J, Jacobs JL, Gilleman U, Loumaye R, et al. Assessing the incidence of gestational diabetes and neonatal outcomes using the IADPSG guidelines in comparison with the Carpenter and Coustan criteria in a Belgian general hospital. Acta Clin Belg 2014;69[1]:8-11.

[55] Carpenter MW, Coustan DR. Criteria for screening tests for gestational diabetes. Obstet Gynecol 1982;144[7]:768-773.

[56] International Association of Diabetes and Pregnancy Study Group. International Association of Diabetes and Pregnancy Study Groups Recommendations on the Diagnosis and Classification of Hyperglycemia in Pregnancy. Diabetes Care 2010 American Diabetes Association;33[3]:676-682.

[57] National Diabetes Data Group. Classification and Diagnosis of Diabetes Mellitus and Other Categories of Glucose Intolerance. Diabetes 1979 American Diabetes Association;28[12]:1039-1057.

[58] Glucose Tolerance in Pregnancy — the Who and How of Testing. The Lancet 1988;2[8621]:1173. 
[59] Di Cianni G, Benzi L, Casadidio I, Orsini P, Rossi L, Fontana G, et al. Screening of gestational diabetes in Tuscany: results in 2000 cases. Ann Ist Super Sanita 1997;33[3]:389-391.

[60] Mello G, Parretti E, Mecacci F, Lucchetti R, Lagazio C, Pratesi M, et al. Risk factors for fetal macrosomia: the importance of a positive oral glucose challenge test. Eur J Endocrinol 1997;137[1]:27-33.

[61] Vitoratos N, Salamalekis E, Bettas P, Kalabokis D, Chrisikopoulos A. Which is the threshold glycose value for further investigation in pregnancy? Clin Exp Obstet Gynecol 1997;24[3]:171-173.

[62] National Diabetes Data Group. Classification and diagnosis of diabetes mellitus and othe categories of glucose intolernace. Diabetes 1979;28[12]:1039-1057.

[63] Razzaghi H, Marcinkevage J, Peterson C. Prevalence of undiagnosed diabetes among non-pregnant women of reproductive age in the United States. , 1999-2010. Prim Care Diabetes 2015; 9[1]: 71-73.

[64] Ferrara A, Kahn HS, Quesenberry CP, Riley C, Hedderson MM. An increase in the incidence of gestational diabetes mellitus: northern California, 1991-2000. Obstet Gynecol 2004;103[3]:526-533 $8 \mathrm{p}$. 


\section{Figures and Tables}

Figure 1 - Flow diagram showing study selection

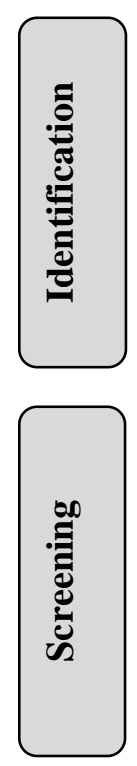

$$
\begin{gathered}
\text { Records identified through database } \\
\text { searching } \\
{[n=3978]}
\end{gathered}
$$
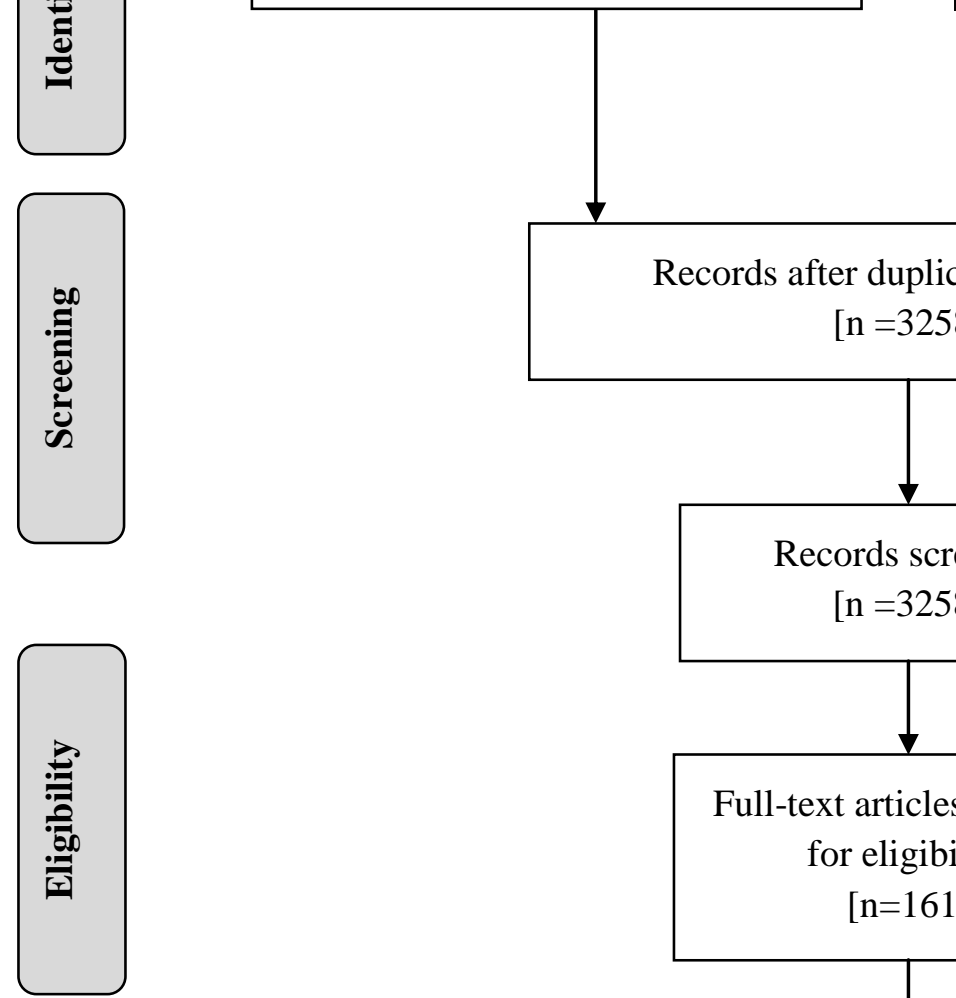

Additional records identified through other sources $[\mathrm{n}=0$ ]

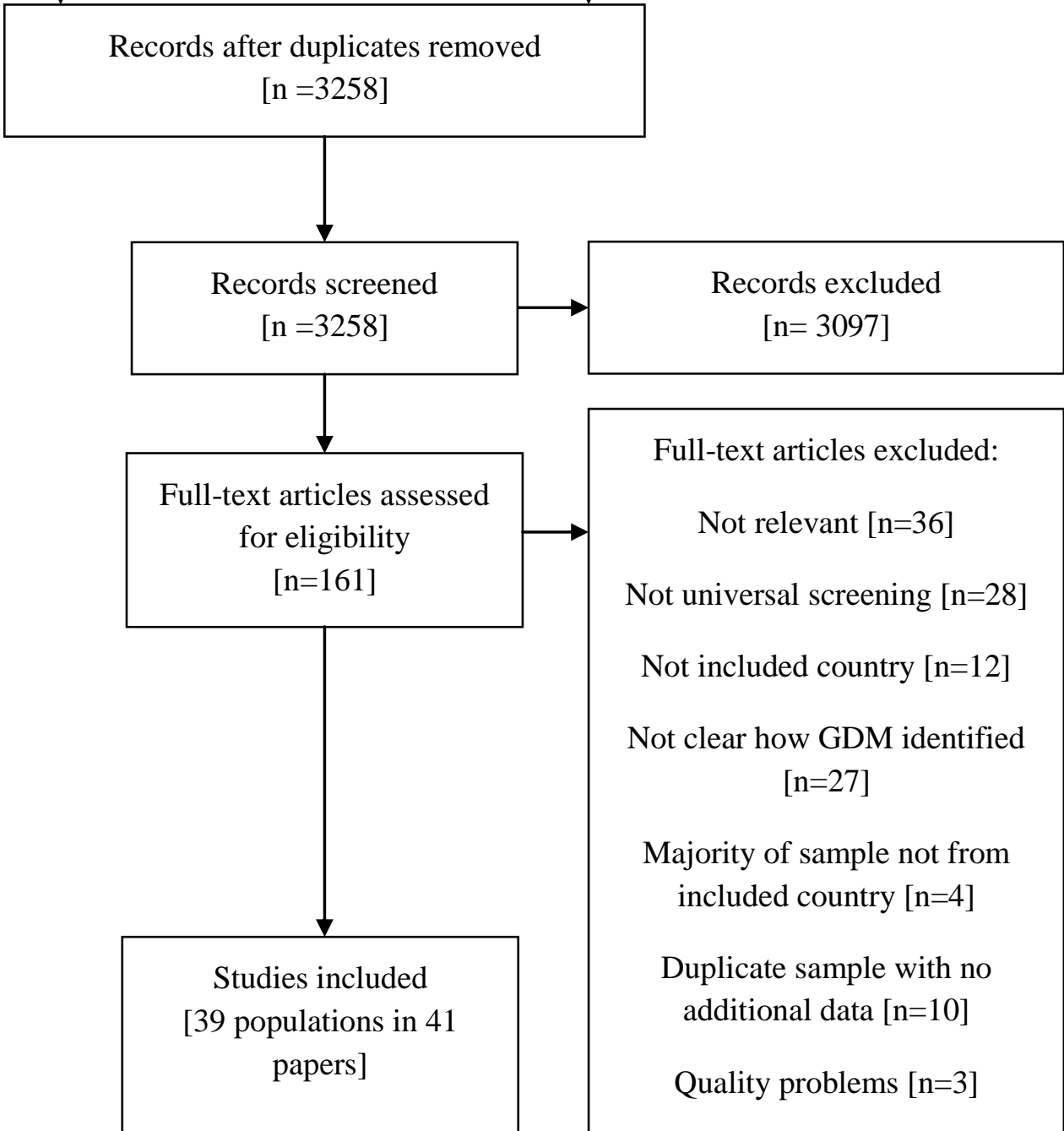


Table 1 - Characteristics of studies included in the review. [Large table included in separate file for publication as supplementary information online]

\begin{tabular}{|c|c|c|c|c|c|c|c|c|c|c|c|}
\hline $\begin{array}{l}\text { First author, } \\
\text { country, } \\
\text { years data } \\
\text { collected }\end{array}$ & $\begin{array}{l}\text { Sampling } \\
\text { Method add } \\
\text { if singleton } \\
\text { or twin }\end{array}$ & $\begin{array}{l}\text { Sample } \\
\text { Size }\end{array}$ & $\begin{array}{l}\text { Mean } \\
\text { Age } \\
{[\mathrm{SD}]}\end{array}$ & $\begin{array}{l}\text { Mean } \\
\text { BMI } \\
{[\mathrm{SD}]}\end{array}$ & $\begin{array}{l}\text { Parity [\% } \\
\text { nulli- } \\
\text { parous] }\end{array}$ & $\begin{array}{l}\text { Family } \\
\text { History }\end{array}$ & $\begin{array}{l}\text { Screening } \\
\text { Type }\end{array}$ & $\begin{array}{l}\text { Gestation } \\
\text { at testing } \\
\text { [weeks] }\end{array}$ & $\begin{array}{l}\text { Criteria Used } \\
\text { [category] }\end{array}$ & $\begin{array}{l}\text { Overall } \\
\text { prevalence } \\
{[95 \% \mathrm{CI}]}\end{array}$ & $\begin{array}{l}\text { Quality } \\
\text { Score }\end{array}$ \\
\hline $\begin{array}{l}\text { Aberg, } \\
\text { Sweden, } \\
\text { 1995-1999 }\end{array}$ & $\begin{array}{l}\text { Prospective } \\
\text { study of all } \\
\text { singleton } \\
\text { pregnant } \\
\text { women in } \\
\text { one } \\
\text { geographic } \\
\text { al area }\end{array}$ & 12,382 & NR & NR & NR & NR & $\begin{array}{l}\text { One step: } \\
75 \mathrm{~g} \\
\text { OGTT }\end{array}$ & $27-28$ & $\begin{array}{l}\text { GDM if } 2 \text { hour } \\
\text { value of } 9 \mathrm{mmol} / \mathrm{l} \text { or } \\
\text { more }\end{array}$ & $\begin{array}{l}1.2 \%[1.0- \\
1.4]\end{array}$ & 2 \\
\hline $\begin{array}{l}\text { Alberico, } \\
\text { Italy, 1997- } \\
2000\end{array}$ & $\begin{array}{l}\text { Prospective } \\
\text { study of all } \\
\text { pregnant } \\
\text { women at } \\
\text { one clinic }\end{array}$ & 856 & 32.5 & NR & $61 \%$ & NR & $\begin{array}{l}\text { Two step: } \\
\text { those with } \\
\text { positive } \\
\text { GCT } \\
\text { given } \\
\text { 100g } \\
\text { OGTT } \\
\end{array}$ & $24-28$ & $\begin{array}{l}\text { GCT of } 7.8 \mathrm{mmol} / 1 \\
\text { or more positive. } \\
\text { GDM diagnosed on } \\
\text { basis of OGTT } \\
\text { according to } \\
\text { Carpenter and } \\
\text { Coustan } \\
\end{array}$ & $\begin{array}{l}6.6 \%[4.9- \\
8.2]\end{array}$ & 3 \\
\hline $\begin{array}{l}\text { Anderberg, } \\
\text { Sweden, } \\
\text { 1991-2003 }\end{array}$ & $\begin{array}{l}\text { Retrospecti } \\
\text { ve of all } \\
\text { pregnant } \\
\text { women in } \\
\text { one } \\
\text { geographic } \\
\text { al area }\end{array}$ & 129,143 & NR & NR & NR & NR & $\begin{array}{l}\text { One step: } \\
75 \mathrm{~g} \\
\text { OGTT }\end{array}$ & 28 & $\begin{array}{l}\text { GDM if } 2 \text { hour } \\
\text { value of } 9 \mathrm{mmol} / 1 \text { or } \\
\text { more }\end{array}$ & $\begin{array}{l}1.2[1.2- \\
1.3]\end{array}$ & 1 \\
\hline $\begin{array}{l}\text { Avalos, } \\
\text { Ireland, } \\
\text { 2007-2009 }\end{array}$ & $\begin{array}{l}\text { Retrospecti } \\
\text { ve study of } \\
\text { all pregnant } \\
\text { women at } \\
\text { five clinics }\end{array}$ & 5,500 & $32[5.3]$ & $\begin{array}{l}26.9 \\
{[5.1]}\end{array}$ & NR & $\begin{array}{l}32 \% \text { in } \\
1^{\text {st }} \text { or } 2^{\text {nd }} \\
\text { degree }\end{array}$ & $\begin{array}{l}\text { One step: } \\
75 \mathrm{~g} \\
\text { OGTT }\end{array}$ & $24-28$ & $\begin{array}{l}\text { OGTT interpreted } \\
\text { according to } \\
\text { IADPSG and WHO } \\
2006\end{array}$ & $\begin{array}{l}\text { IADPSG: } \\
12.4 \% \\
{[11.5-13.3]} \\
\text { WHO } \\
2006: 9.4 \%\end{array}$ & 3 \\
\hline
\end{tabular}




\begin{tabular}{|c|c|c|c|c|c|c|c|c|c|c|c|}
\hline $\begin{array}{l}\text { First author, } \\
\text { country, } \\
\text { years data } \\
\text { collected }\end{array}$ & $\begin{array}{l}\text { Sampling } \\
\text { Method add } \\
\text { if singleton } \\
\text { or twin }\end{array}$ & $\begin{array}{l}\text { Sample } \\
\text { Size }\end{array}$ & $\begin{array}{l}\text { Mean } \\
\text { Age } \\
{[\mathrm{SD}]}\end{array}$ & $\begin{array}{l}\text { Mean } \\
\text { BMI } \\
{[\text { SD] }}\end{array}$ & $\begin{array}{l}\text { Parity [\% } \\
\text { nulli- } \\
\text { parous] }\end{array}$ & $\begin{array}{l}\text { Family } \\
\text { History }\end{array}$ & $\begin{array}{l}\text { Screening } \\
\text { Type }\end{array}$ & $\begin{array}{l}\text { Gestation } \\
\text { at testing } \\
\text { [weeks] }\end{array}$ & $\begin{array}{l}\text { Criteria Used } \\
\text { [category] }\end{array}$ & $\begin{array}{l}\text { Overall } \\
\text { prevalence } \\
{[95 \% \mathrm{CI}]}\end{array}$ & $\begin{array}{l}\text { Quality } \\
\text { Score }\end{array}$ \\
\hline & & & & & & & & & & {$[8.7-10.2]$} & \\
\hline $\begin{array}{l}\text { Breschi, } \\
\text { Italy, 1988- } \\
1991\end{array}$ & $\begin{array}{l}\text { Prospective } \\
\text { study of all } \\
\text { pregnant } \\
\text { women at } \\
\text { one clinic }\end{array}$ & 539 & $\begin{array}{l}29.4 \\
{[4.6]}\end{array}$ & $\begin{array}{l}22.5 \\
{[3.3]}\end{array}$ & Mean: 1.7 & $34.2 \%$ & $\begin{array}{l}\text { One step: } \\
\text { 100g } \\
\text { OGTT }\end{array}$ & $\begin{array}{l}\text { Mean }= \\
26\end{array}$ & $\begin{array}{l}\text { OGTT interpreted } \\
\text { according to } \\
\text { NDDG }\end{array}$ & $\begin{array}{l}3.2 \%[1.7- \\
4.6]\end{array}$ & 3 \\
\hline $\begin{array}{l}\text { Bugallo, } \\
\text { Spain, 2004- } \\
2006\end{array}$ & $\begin{array}{l}\text { Retrospecti } \\
\text { ve study of } \\
\text { all pregnant } \\
\text { women at } \\
\text { one } \\
\text { hospital }\end{array}$ & 11,628 & $30[6]$ & NR & NR & NR & $\begin{array}{l}\text { Two step: } \\
\text { those with } \\
\text { positive } \\
50 \text { g GCT } \\
\text { given } \\
100 \mathrm{~g} \\
\text { OGTT }\end{array}$ & $24-28$ & $\begin{array}{l}\text { GCT of } 7.8 \mathrm{mmol} / 1 \\
\text { or more positive. } \\
\text { GDM diagnosed on } \\
\text { basis of OGTT } \\
\text { according to } \\
\text { Carpenter and } \\
\text { Coustan }\end{array}$ & $\begin{array}{l}6.4 \%[5.9- \\
6.9]\end{array}$ & 1 \\
\hline $\begin{array}{l}\text { Cauza, } \\
\text { Austria, } \\
1999-2001\end{array}$ & $\begin{array}{l}\text { Prospective } \\
\text { study of all } \\
\text { pregnant } \\
\text { women at } \\
\text { one } \\
\text { hospital }\end{array}$ & 2,421 & NR & NR & NR & NR & $\begin{array}{l}\text { One step: } \\
75 \mathrm{~g} \\
\text { OGTT }\end{array}$ & $24-28$ & $\begin{array}{l}\text { GDM if } 1 \text { hour } \\
\text { value of } 8.9 \mathrm{mmol} / 1 \\
\text { or more }\end{array}$ & $\begin{array}{l}8.6 \%[7.5- \\
9.7]\end{array}$ & 3 \\
\hline $\begin{array}{l}\text { Chevalier, } \\
\text { France, } \\
\text { 2002-2006 }\end{array}$ & $\begin{array}{l}\text { Prospective } \\
\text { study of all } \\
\text { pregnant } \\
\text { women at } \\
\text { one } \\
\text { hospital }\end{array}$ & 11,545 & NR & NR & $46 \%$ & NR & $\begin{array}{l}\text { Two step: } \\
\text { those with } \\
\text { positive } \\
\text { GCT } \\
\text { given } \\
\text { 100g } \\
\text { OGTT }\end{array}$ & $24-28$ & $\begin{array}{l}\text { GCT of } 7.2 \mathrm{mmol} / 1 \\
\text { or more positive. } \\
\text { GDM diagnosed on } \\
\text { basis of OGTT } \\
\text { according to } \\
\text { Carpenter and } \\
\text { Coustan }\end{array}$ & $\begin{array}{l}4.3 \%[3.9- \\
4.6]\end{array}$ & 1 \\
\hline $\begin{array}{l}\text { Chico, } \\
\text { Spain, 1999- } \\
2001\end{array}$ & $\begin{array}{l}\text { Retrospecti } \\
\text { ve study of } \\
\text { all pregnant }\end{array}$ & 6,428 & NR & NR & NR & NR & $\begin{array}{l}\text { Two step: } \\
\text { those with } \\
\text { positive }\end{array}$ & $24-28$ & $\begin{array}{l}\text { GCT of } 7.8 \mathrm{mmol} / 1 \\
\text { or more positive. } \\
\text { GDM diagnosed on }\end{array}$ & $\begin{array}{l}\text { NDDG: } \\
6.5 \%[5.9- \\
7.1] \\
\end{array}$ & 1 \\
\hline
\end{tabular}




\begin{tabular}{|c|c|c|c|c|c|c|c|c|c|c|c|}
\hline $\begin{array}{l}\text { First author, } \\
\text { country, } \\
\text { years data } \\
\text { collected }\end{array}$ & $\begin{array}{l}\text { Sampling } \\
\text { Method add } \\
\text { if singleton } \\
\text { or twin }\end{array}$ & $\begin{array}{l}\text { Sample } \\
\text { Size }\end{array}$ & $\begin{array}{l}\text { Mean } \\
\text { Age } \\
{[\mathrm{SD}]}\end{array}$ & $\begin{array}{l}\text { Mean } \\
\text { BMI } \\
{[\mathrm{SD}]}\end{array}$ & $\begin{array}{l}\text { Parity [\% } \\
\text { nulli- } \\
\text { parous] }\end{array}$ & $\begin{array}{l}\text { Family } \\
\text { History }\end{array}$ & $\begin{array}{l}\text { Screening } \\
\text { Type }\end{array}$ & $\begin{array}{l}\text { Gestation } \\
\text { at testing } \\
\text { [weeks] }\end{array}$ & $\begin{array}{l}\text { Criteria Used } \\
\text { [category] }\end{array}$ & $\begin{array}{l}\text { Overall } \\
\text { prevalence } \\
{[95 \% \mathrm{CI}]}\end{array}$ & $\begin{array}{l}\text { Quality } \\
\text { Score }\end{array}$ \\
\hline & $\begin{array}{l}\text { women at a } \\
\text { set of } \\
\text { clinics }\end{array}$ & & & & & & $\begin{array}{l}\text { GCT } \\
\text { given } \\
100 \mathrm{~g} \\
\text { OGTT }\end{array}$ & & $\begin{array}{l}\text { basis of OGTT } \\
\text { according to } \\
\text { NDDG Carpenter } \\
\text { and Coustan }\end{array}$ & $\begin{array}{l}\text { Carpenter } \\
\text { and } \\
\text { Coustan: } \\
6.8 \%[6.1- \\
7.4]\end{array}$ & \\
\hline $\begin{array}{l}\text { Coolen, } \\
\text { Belgium, } \\
2008\end{array}$ & $\begin{array}{l}\text { Prospective } \\
\text { study of all } \\
\text { pregnant } \\
\text { women } \\
\text { attending } \\
\text { one clinic }\end{array}$ & 317 & $\begin{array}{l}30.6[0.3 \\
]\end{array}$ & NR & $33.9 \%$ & NR & $\begin{array}{l}\text { Two step: } \\
\text { those with } \\
\text { positive } \\
\text { GCT } \\
\text { given } \\
\text { 100g } \\
\text { OGTT }\end{array}$ & $24-28$ & $\begin{array}{l}\text { GCT of } 7.8 \mathrm{mmol} / 1 \\
\text { or more positive. } \\
\text { GDM diagnosed on } \\
\text { basis of OGTT } \\
\text { according to } \\
\text { Carpenter and } \\
\text { Coustan }\end{array}$ & $\begin{array}{l}3.2 \%[1.2- \\
5.1]\end{array}$ & 1 \\
\hline $\begin{array}{l}\text { Cordero, } \\
\text { Spain, NR }\end{array}$ & $\begin{array}{l}\text { Randomise } \\
\mathrm{d} \text { controlled } \\
\text { trial of } \\
\text { pregnant } \\
\text { women in } \\
\text { one area. }\end{array}$ & 156 & $\begin{array}{l}32.9 \\
{[4.5]}\end{array}$ & $23.6[4]$ & $47.4 \%$ & $\begin{array}{l}14.1 \% \\
1^{\text {st }} \\
\text { degree } \\
\text { and } 32 \% \\
2^{\text {nd }} \\
\text { degree. }\end{array}$ & $\begin{array}{l}\text { Two step: } \\
\text { those with } \\
\text { positive } \\
\text { GCT } \\
\text { given } \\
\text { 100g } \\
\text { OGTT }\end{array}$ & $24-28$ & $\begin{array}{l}\text { GCT of } 7.8 \mathrm{mmol} / 1 \\
\text { or more positive. } \\
\text { GDM diagnosed on } \\
\text { basis of OGTT } \\
\text { according to } \\
\text { NDDG }\end{array}$ & $\begin{array}{l}8.3 \%[4- \\
12.7]\end{array}$ & 2 \\
\hline $\begin{array}{l}\text { Corrado, } \\
\text { Italy, } 1990\end{array}$ & $\begin{array}{l}\text { Retrospecti } \\
\text { ve study of } \\
\text { all } \\
\text { singleton } \\
\text { pregnant } \\
\text { women } \\
\text { seen by } 6 \\
\text { obstetrician } \\
\text { s }\end{array}$ & 738 & NR & NR & NR & NR & $\begin{array}{l}\text { One step: } \\
75 \mathrm{~g} \\
\text { OGTT }\end{array}$ & $24-28$ & $\begin{array}{l}\text { OGTT interpreted } \\
\text { according to } \\
\text { IADPSG }\end{array}$ & $\begin{array}{l}11.9 \% \text { [9.6- } \\
14.3]\end{array}$ & 1 \\
\hline Cosson, & Prospective & 2,111 & 29.2 & 23.4 & Mean & $12.8 \%$ & One step: & $24-28$ & OGTT interpreted & $12.6 \%$ & 1 \\
\hline
\end{tabular}




\begin{tabular}{|c|c|c|c|c|c|c|c|c|c|c|c|}
\hline $\begin{array}{l}\text { First author, } \\
\text { country, } \\
\text { years data } \\
\text { collected }\end{array}$ & $\begin{array}{l}\text { Sampling } \\
\text { Method add } \\
\text { if singleton } \\
\text { or twin }\end{array}$ & $\begin{array}{l}\text { Sample } \\
\text { Size }\end{array}$ & $\begin{array}{l}\text { Mean } \\
\text { Age } \\
{[\mathrm{SD}]}\end{array}$ & $\begin{array}{l}\text { Mean } \\
\text { BMI } \\
{[\mathrm{SD}]}\end{array}$ & $\begin{array}{l}\text { Parity [\% } \\
\text { nulli- } \\
\text { parous] }\end{array}$ & $\begin{array}{l}\text { Family } \\
\text { History }\end{array}$ & $\begin{array}{l}\text { Screening } \\
\text { Type }\end{array}$ & $\begin{array}{l}\text { Gestation } \\
\text { at testing } \\
\text { [weeks] }\end{array}$ & $\begin{array}{l}\text { Criteria Used } \\
\text { [category] }\end{array}$ & $\begin{array}{l}\text { Overall } \\
\text { prevalence } \\
{[95 \% \mathrm{CI}]}\end{array}$ & $\begin{array}{l}\text { Quality } \\
\text { Score }\end{array}$ \\
\hline France, 2002 & $\begin{array}{l}\text { study of all } \\
\text { singleton } \\
\text { pregnant } \\
\text { women at } \\
\text { one } \\
\text { hospital }\end{array}$ & & [5.8] & {$[4.7]$} & $\begin{array}{l}2.08[\mathrm{SD} \\
1.37]\end{array}$ & & $\begin{array}{l}75 g \\
\text { OGTT }\end{array}$ & & $\begin{array}{l}\text { according if fasting } \\
\text { value } 5.3 \mathrm{mmol} / 1 \text { or } \\
\text { more [French } \\
\text { recommendations] } \\
\text { and/or } 2 \text { hour value } \\
\text { of } 7.8 \mathrm{mmol} / 1 \text { or } \\
\text { more [according to } \\
\text { WHO 1999]. }\end{array}$ & [11.1-14.0] & \\
\hline $\begin{array}{l}\text { Di Cianni, } \\
\text { Italy, 1995- } \\
2001\end{array}$ & $\begin{array}{l}\text { Retrospecti } \\
\text { ve study of } \\
\text { all pregnant } \\
\text { women at } \\
\text { one clinic. }\end{array}$ & 3,950 & $\begin{array}{l}31.1 \\
{[4.7]}\end{array}$ & $\begin{array}{l}22.5 \\
{[3.7]}\end{array}$ & $56.1 \%$ & $17.1 \%$ & $\begin{array}{l}\text { Two step: } \\
\text { those with } \\
\text { positive } \\
\text { GCT } \\
\text { given } \\
\text { 100g } \\
\text { OGTT }\end{array}$ & $24-28$ & $\begin{array}{l}\text { GCT of } 7.8 \mathrm{mmol} / 1 \\
\text { or more positive. } \\
\text { GDM diagnosed on } \\
\text { basis of OGTT } \\
\text { according to } \\
\text { Carpenter and } \\
\text { Coustan }\end{array}$ & $\begin{array}{l}8.4 \%[7.6- \\
9.3]\end{array}$ & 1 \\
\hline $\begin{array}{l}\text { Duran, } \\
\text { Spain, 2011- } \\
2012 \text { cohort } \\
1\end{array}$ & $\begin{array}{l}\text { Prospective } \\
\text { study of all } \\
\text { pregnant } \\
\text { women at } \\
\text { one } \\
\text { hospital }\end{array}$ & 1,750 & 32 & $\begin{array}{l}\text { Median } \\
22.7\end{array}$ & $43.9 \%$ & $8.4 \%$ & $\begin{array}{l}\text { Two step: } \\
\text { those with } \\
\text { positive } \\
50 \mathrm{~g} \mathrm{GCT} \\
\text { given } \\
100 \mathrm{~g} \\
\text { OGTT }\end{array}$ & $24-28$ & $\begin{array}{l}\text { GCT of } 7.8 \mathrm{mmol} / 1 \\
\text { or more positive. } \\
\text { GDM diagnosed on } \\
\text { basis of OGTT } \\
\text { according to } \\
\text { Carpenter and } \\
\text { Coustan }\end{array}$ & $\begin{array}{l}10.6 \%[9.1- \\
12.0]\end{array}$ & 1 \\
\hline $\begin{array}{l}\text { Duran, } \\
\text { Spain, 2012- } \\
2013 \text { cohort } \\
2\end{array}$ & $\begin{array}{l}\text { All } \\
\text { pregnant } \\
\text { women at } \\
\text { one } \\
\text { hospital }\end{array}$ & 1,526 & 32 & $\begin{array}{l}\text { Median } \\
22.8\end{array}$ & $44.7 \%$ & $9.4 \%$ & $\begin{array}{l}\text { One step: } \\
75 \mathrm{~g} \\
\text { OGTT }\end{array}$ & $24-28$ & $\begin{array}{l}\text { GDM diagnosed } \\
\text { according to } \\
\text { IADPSG }\end{array}$ & $\begin{array}{l}35.5 \% \\
{[33.1-37.9]}\end{array}$ & 1 \\
\hline $\begin{array}{l}\text { Fadl, } \\
\text { Sweden, }\end{array}$ & $\begin{array}{l}\text { Retrospecti } \\
\text { ve study of }\end{array}$ & $\begin{array}{l}1,260,29 \\
7\end{array}$ & NR & NR & $42 \%$ & NR & $\begin{array}{l}\text { Two step: } \\
\text { those with }\end{array}$ & NR & $\begin{array}{l}\text { RBG of } 8 \mathrm{mmol} / 1 \text { or } \\
\text { higher considered }\end{array}$ & $\begin{array}{l}0.84 \% \\
{[0.82-0.86]}\end{array}$ & 1 \\
\hline
\end{tabular}




\begin{tabular}{|c|c|c|c|c|c|c|c|c|c|c|c|}
\hline $\begin{array}{l}\text { First author, } \\
\text { country, } \\
\text { years data } \\
\text { collected }\end{array}$ & $\begin{array}{l}\text { Sampling } \\
\text { Method add } \\
\text { if singleton } \\
\text { or twin }\end{array}$ & $\begin{array}{l}\text { Sample } \\
\text { Size }\end{array}$ & $\begin{array}{l}\text { Mean } \\
\text { Age } \\
{[\mathrm{SD}]}\end{array}$ & $\begin{array}{l}\text { Mean } \\
\text { BMI } \\
{[\mathrm{SD}]}\end{array}$ & $\begin{array}{l}\text { Parity [\% } \\
\text { nulli- } \\
\text { parous] }\end{array}$ & $\begin{array}{l}\text { Family } \\
\text { History }\end{array}$ & $\begin{array}{l}\text { Screening } \\
\text { Type }\end{array}$ & $\begin{array}{l}\text { Gestation } \\
\text { at testing } \\
\text { [weeks] }\end{array}$ & $\begin{array}{l}\text { Criteria Used } \\
\text { [category] }\end{array}$ & $\begin{array}{l}\text { Overall } \\
\text { prevalence } \\
{[95 \% \mathrm{CI}]}\end{array}$ & $\begin{array}{l}\text { Quality } \\
\text { Score }\end{array}$ \\
\hline 1991-2003 & $\begin{array}{l}\text { all } \\
\text { singleton } \\
\text { pregnant } \\
\text { women in } \\
\text { Sweden }\end{array}$ & & & & & & $\begin{array}{l}\text { positive } \\
\text { RBG } \\
\text { given } 75 \mathrm{~g} \\
\text { OGTT }\end{array}$ & & $\begin{array}{l}\text { positive. GDM } \\
\text { diagnosed on basis } \\
\text { of } 75 \mathrm{~g} \text { OGTT if } \\
\text { fasting value } \\
6.1 \mathrm{mmol} / 1 \text { and/or } 2 \\
\text { hour value of } \\
9 \mathrm{mmol} / \mathrm{l} \text { or more. }\end{array}$ & & \\
\hline $\begin{array}{l}\text { Fedele, Italy, } \\
1990-1991\end{array}$ & $\begin{array}{l}\text { Prospective } \\
\text { study of all } \\
\text { women } \\
\text { attending } \\
\text { family } \\
\text { planning } \\
\text { clinics in } \\
\text { one area }\end{array}$ & 490 & NR & NR & NR & NR & $\begin{array}{l}\text { Two step: } \\
\text { those with } \\
\text { positive } \\
50 \mathrm{~g} \text { GCT } \\
\text { given } \\
100 \mathrm{~g} \\
\text { OGTT }\end{array}$ & $\begin{array}{l}\text { High risk } \\
\text { women } \\
10-14,24- \\
28 \text { and } \\
30-32 . \\
\text { Others } \\
24-28 .\end{array}$ & $\begin{array}{l}\text { GCT of } 7.8 \mathrm{mmol} / 1 \\
\text { or more positive. } \\
\text { GDM diagnosed on } \\
\text { basis of OGTT } \\
\text { according to } \\
\text { Carpenter and } \\
\text { Coustan }\end{array}$ & $\begin{array}{l}10.8 \%[8.1- \\
13.6]\end{array}$ & 1 \\
\hline $\begin{array}{l}\text { Griffin, } \\
\text { Ireland, NR }\end{array}$ & $\begin{array}{l}\text { All women } \\
\text { attending } \\
\text { one } \\
\text { hospital } \\
\text { randomised } \\
\text { to selective } \\
\text { or universal } \\
\text { screening }\end{array}$ & 1299 & $\begin{array}{l}27.4 \\
{[5.6]}\end{array}$ & $\begin{array}{l}\text { During } \\
\text { pregnan } \\
\text { cy } 28.2 \\
{[4]}\end{array}$ & $39.3 \%$ & NR & $\begin{array}{l}\text { Two step: } \\
\text { those with } \\
\text { positive } \\
50 \mathrm{~g} \text { GCT } \\
\text { given } \\
100 \mathrm{~g} \\
\text { OGTT }\end{array}$ & $26-28$ & $\begin{array}{l}\text { GCT of } 7.8 \mathrm{mmol} / 1 \\
\text { or more positive. } \\
\text { GDM diagnosed on } \\
\text { basis of OGTT } \\
\text { according to } \\
\text { Carpenter and } \\
\text { Coustan }\end{array}$ & $\begin{array}{l}2.7 \%[1.8- \\
3.6]\end{array}$ & 2 \\
\hline $\begin{array}{l}\text { Ignell, } \\
\text { Sweden, } \\
2014\end{array}$ & $\begin{array}{l}\text { Retrospecti } \\
\text { ve study of } \\
\text { all } \\
\text { singleton }\end{array}$ & 156,144 & NR & NR & NR & NR & $\begin{array}{l}\text { One step: } \\
75 \mathrm{~g} \\
\text { OGTT }\end{array}$ & 28 & $\begin{array}{l}\text { GDM if } 2 \text { hour } \\
\text { value of } 9 \mathrm{mmol} / \mathrm{l} \text { or } \\
\text { more }\end{array}$ & $\begin{array}{l}2.2 \%[2.1- \\
2.3]\end{array}$ & 1 \\
\hline
\end{tabular}




\begin{tabular}{|c|c|c|c|c|c|c|c|c|c|c|c|}
\hline $\begin{array}{l}\text { First author, } \\
\text { country, } \\
\text { years data } \\
\text { collected }\end{array}$ & $\begin{array}{l}\text { Sampling } \\
\text { Method add } \\
\text { if singleton } \\
\text { or twin }\end{array}$ & $\begin{array}{l}\text { Sample } \\
\text { Size }\end{array}$ & $\begin{array}{l}\text { Mean } \\
\text { Age } \\
{[\mathrm{SD}]}\end{array}$ & $\begin{array}{l}\text { Mean } \\
\text { BMI } \\
{[\mathrm{SD}]}\end{array}$ & $\begin{array}{l}\text { Parity [\% } \\
\text { nulli- } \\
\text { parous] }\end{array}$ & $\begin{array}{l}\text { Family } \\
\text { History }\end{array}$ & $\begin{array}{l}\text { Screening } \\
\text { Type }\end{array}$ & $\begin{array}{l}\text { Gestation } \\
\text { at testing } \\
\text { [weeks] }\end{array}$ & $\begin{array}{l}\text { Criteria Used } \\
\text { [category] }\end{array}$ & $\begin{array}{l}\text { Overall } \\
\text { prevalence } \\
{[95 \% \mathrm{CI}]}\end{array}$ & $\begin{array}{l}\text { Quality } \\
\text { Score }\end{array}$ \\
\hline & $\begin{array}{l}\text { pregnant } \\
\text { women in } \\
\text { two areas. }\end{array}$ & & & & & & & & & & \\
\hline $\begin{array}{l}\text { Janghornban } \\
\text { i, UK, 1996- } \\
1997\end{array}$ & $\begin{array}{l}\text { Prospective } \\
\text { study of all } \\
\text { pregnant } \\
\text { women } \\
\text { screened in } \\
\text { one area. }\end{array}$ & 3,933 & NR & NR & NR & NR & $\begin{array}{l}\text { Two step: } \\
\text { those with } \\
\text { positive } \\
\text { RBG } \\
\text { given } 75 \mathrm{~g} \\
\text { OGTT }\end{array}$ & $24-28$ & $\begin{array}{l}\text { RBG of } 6.5 \mathrm{mmol} / 1 \\
\text { or more positive. } \\
\text { GDM diagnosed } \\
\text { according to OGTT } \\
\text { if } 2 \text { hour reading of } \\
11 \mathrm{mmol} / 1 \text { or more } \\
\end{array}$ & $\begin{array}{l}1.7 \%[1.3- \\
2.1]\end{array}$ & 1 \\
\hline $\begin{array}{l}\text { Jiménez- } \\
\text { Moleón, } \\
\text { Spain, } 1995\end{array}$ & $\begin{array}{l}\text { Retrospecti } \\
\text { ve study of } \\
\text { all } \\
\text { singleton } \\
\text { pregnant } \\
\text { women in } \\
\text { one } \\
\text { hospital. }\end{array}$ & 1,962 & NR & NR & NR & NR & $\begin{array}{l}\text { Two step: } \\
\text { those with } \\
\text { positive } \\
\text { GCT } \\
\text { given } \\
\text { 100g } \\
\text { OGTT }\end{array}$ & $24-28$ & $\begin{array}{l}\text { GCT of } 7.8 \mathrm{mmol} / 1 \\
\text { or more positive. } \\
\text { GDM diagnosed on } \\
\text { basis of OGTT } \\
\text { according to } \\
\text { NDDG }\end{array}$ & $\begin{array}{l}3.3 \%[2.5- \\
4.1]\end{array}$ & 1 \\
\hline $\begin{array}{l}\text { Kayema- } \\
\text { Kay, UK, } \\
1996-1997\end{array}$ & $\begin{array}{l}\text { Prospective } \\
\text { study of all } \\
\text { singleton } \\
\text { women at } \\
\text { one } \\
\text { hospital } \\
\end{array}$ & 1484 & NR & NR & NR & NR & $\begin{array}{l}\text { One step: } \\
75 \mathrm{~g} \\
\text { OGTT }\end{array}$ & $24-28$ & $\begin{array}{l}\text { GDM if } 2 \text { hour } \\
\text { value of } 9.0 \mathrm{mmol} / 1 \\
\text { or more }\end{array}$ & $\begin{array}{l}1.2 \%[0.7- \\
1.8\end{array}$ & \\
\hline $\begin{array}{l}\text { Lacaria, } \\
\text { Italy, 2012- } \\
2013\end{array}$ & $\begin{array}{l}\text { Prospective } \\
\text { study of all } \\
\text { pregnant } \\
\text { women in } \\
\text { two areas. }\end{array}$ & 2497 & $33.5[5]$ & $22.8[4]$ & NR & NR & $\begin{array}{l}\text { One step: } \\
75 \mathrm{~g} \\
\text { OGTT }\end{array}$ & $24-28$ & $\begin{array}{l}\text { OGTT interpreted } \\
\text { according to } \\
\text { IADPSG }\end{array}$ & $10.9 \%$ & 1 \\
\hline Lind, UK, & Prospective & 2,285 & NR & NR & NR & NR & Two step: & $28-32$ & RBG greater than & $0.3 \%[0.1-$ & 1 \\
\hline
\end{tabular}




\begin{tabular}{|c|c|c|c|c|c|c|c|c|c|c|c|}
\hline $\begin{array}{l}\text { First author, } \\
\text { country, } \\
\text { years data } \\
\text { collected }\end{array}$ & $\begin{array}{l}\text { Sampling } \\
\text { Method add } \\
\text { if singleton } \\
\text { or twin }\end{array}$ & $\begin{array}{l}\text { Sample } \\
\text { Size }\end{array}$ & $\begin{array}{l}\text { Mean } \\
\text { Age } \\
{[\mathrm{SD}]}\end{array}$ & $\begin{array}{l}\text { Mean } \\
\text { BMI } \\
{[\text { SD }]}\end{array}$ & $\begin{array}{l}\text { Parity [\% } \\
\text { nulli- } \\
\text { parous] }\end{array}$ & $\begin{array}{l}\text { Family } \\
\text { History }\end{array}$ & $\begin{array}{l}\text { Screening } \\
\text { Type }\end{array}$ & $\begin{array}{l}\text { Gestation } \\
\text { at testing } \\
\text { [weeks] }\end{array}$ & $\begin{array}{l}\text { Criteria Used } \\
\text { [category] }\end{array}$ & $\begin{array}{l}\text { Overall } \\
\text { prevalence } \\
{[95 \% \mathrm{CI}]}\end{array}$ & $\begin{array}{l}\text { Quality } \\
\text { Score }\end{array}$ \\
\hline 1984 & $\begin{array}{l}\text { study of all } \\
\text { singleton } \\
\text { pregnant } \\
\text { women in } \\
\text { one clinic. }\end{array}$ & & & & & & $\begin{array}{l}\text { those with } \\
\text { positive } \\
\text { RBG } \\
\text { given } 75 \mathrm{~g} \\
\text { OGTT }\end{array}$ & & $\begin{array}{l}4.3 \mathrm{mmol} / 1 \text { to } \\
6.4 \mathrm{mmol} / 1 \\
\text { [depending on time } \\
\text { since meal] } \\
\text { considered positive. } \\
\text { GDM diagnosed on } \\
\text { the basis of OGTT } \\
2 \text { hour value of } \\
8.0 \mathrm{mmol} / \mathrm{l} \text { and } \\
\text { above. }\end{array}$ & $0.5]$ & \\
\hline $\begin{array}{l}\text { Lindqvist, } \\
\text { Sweden, } \\
\text { 2011-2012 }\end{array}$ & $\begin{array}{l}\text { Population } \\
\text { study of all } \\
\text { pregnant } \\
\text { women in } \\
\text { areas where } \\
\text { universal } \\
\text { screening } \\
\text { offered }\end{array}$ & 20,822 & 30 & 25 & NR & NR & $\begin{array}{l}\text { One step: } \\
75 \mathrm{~g} \\
\text { OGTT }\end{array}$ & NR & $\begin{array}{l}\text { GDM if } 2 \text { hour } \\
\text { value over } \\
10 \mathrm{mmol} / 1\end{array}$ & $\begin{array}{l}2.2 \%[2- \\
2.4]\end{array}$ & 1 \\
\hline $\begin{array}{l}\text { Malmqvist, } \\
\text { Sweden, } \\
\text { 1999-2005 }\end{array}$ & $\begin{array}{l}\text { Retrospecti } \\
\text { ve study of } \\
\text { all } \\
\text { singleton } \\
\text { pregnant } \\
\text { women in } \\
\text { one area }\end{array}$ & 81,110 & 30.4 [5] & NR & $47.3 \%$ & NR & $\begin{array}{l}\text { One step: } \\
75 \mathrm{~g} \\
\text { OGTT }\end{array}$ & 28 & $\begin{array}{l}\text { GDM if } 2 \text { hour } \\
\text { value over } \\
10 \mathrm{mmol} / 1\end{array}$ & $\begin{array}{l}2 \%[1.9- \\
2.1]\end{array}$ & 1 \\
\hline $\begin{array}{l}\text { Meek, UK, } \\
\text { 2004-2008 }\end{array}$ & $\begin{array}{l}\text { Retrospecti } \\
\text { ve study of } \\
\text { all } \\
\text { singleton } \\
\end{array}$ & 25,543 & $\begin{array}{l}30.7[95 \\
\% \mathrm{CI} \\
30.6- \\
30.8]\end{array}$ & $\begin{array}{l}24.8 \\
{[95 \% \mathrm{CI}} \\
24.6- \\
24.8]\end{array}$ & $38.7 \%$ & NR & $\begin{array}{l}\text { Two step: } \\
\text { those with } \\
\text { positive } \\
\text { GCT }\end{array}$ & $26-28$ & $\begin{array}{l}\text { GCT of } 7.8 \mathrm{mmol} / 1 \\
\text { or more positive. } \\
\text { GDM diagnosed on } \\
\text { basis of } 75 \mathrm{~g} \text { OGTT }\end{array}$ & $\begin{array}{l}4.9 \%[4.6- \\
5.2]\end{array}$ & 1 \\
\hline
\end{tabular}




\begin{tabular}{|c|c|c|c|c|c|c|c|c|c|c|c|}
\hline $\begin{array}{l}\text { First author, } \\
\text { country, } \\
\text { years data } \\
\text { collected }\end{array}$ & $\begin{array}{l}\text { Sampling } \\
\text { Method add } \\
\text { if singleton } \\
\text { or twin }\end{array}$ & $\begin{array}{l}\text { Sample } \\
\text { Size }\end{array}$ & $\begin{array}{l}\text { Mean } \\
\text { Age } \\
{[\mathrm{SD}]}\end{array}$ & $\begin{array}{l}\text { Mean } \\
\text { BMI } \\
{[\text { SD] }}\end{array}$ & $\begin{array}{l}\text { Parity [\% } \\
\text { nulli- } \\
\text { parous] }\end{array}$ & $\begin{array}{l}\text { Family } \\
\text { History }\end{array}$ & $\begin{array}{l}\text { Screening } \\
\text { Type }\end{array}$ & $\begin{array}{l}\text { Gestation } \\
\text { at testing } \\
\text { [weeks] }\end{array}$ & $\begin{array}{l}\text { Criteria Used } \\
\text { [category] }\end{array}$ & $\begin{array}{l}\text { Overall } \\
\text { prevalence } \\
{[95 \% \mathrm{CI}]}\end{array}$ & $\begin{array}{l}\text { Quality } \\
\text { Score }\end{array}$ \\
\hline & $\begin{array}{l}\text { pregnant } \\
\text { women in } \\
\text { one area }\end{array}$ & & & & & & $\begin{array}{l}\text { given } 75 \mathrm{~g} \\
\text { OGTT }\end{array}$ & & $\begin{array}{l}\text { interpreted } \\
\text { according to } \\
\text { IADPSG }\end{array}$ & & \\
\hline $\begin{array}{l}\text { Miailhe, } \\
\text { France, } \\
2011-2012\end{array}$ & $\begin{array}{l}\text { Prospective } \\
\text { study of all } \\
\text { singleton } \\
\text { pregnant } \\
\text { women in } \\
\text { one area }\end{array}$ & 2,187 & NR & $\begin{array}{l}36 \% \\
\text { with } \\
\text { BMI } \\
>25\end{array}$ & $41.7 \%$ & NR & $\begin{array}{l}\text { One step: } \\
75 \mathrm{~g} \\
\text { OGTT }\end{array}$ & $24-28$ & $\begin{array}{l}\text { GDM diagnosed } \\
\text { according to } \\
\text { IADPSG }\end{array}$ & $\begin{array}{l}14 \%[12.7- \\
15.6]\end{array}$ & 1 \\
\hline $\begin{array}{l}\text { Murgia, } \\
\text { Italy, NR }\end{array}$ & $\begin{array}{l}\text { Prospective } \\
\text { study of } \\
\text { pregnant } \\
\text { women at } \\
\text { one clinic }\end{array}$ & 1,103 & $31[5]$ & $\begin{array}{l}22.5 \\
{[3.8]}\end{array}$ & NR & $\begin{array}{l}14.2 \% \\
1^{\text {st }} \\
\text { degree }\end{array}$ & $\begin{array}{l}\text { Two step: } \\
\text { those with } \\
\text { positive } \\
\text { GCT } \\
\text { given } \\
\text { 100g } \\
\text { OGTT }\end{array}$ & $\begin{array}{l}16-18,24- \\
26 \text { and } \\
30-32\end{array}$ & $\begin{array}{l}\text { GCT of } 7.2 \mathrm{mmol} / 1 \\
\text { or more positive. } \\
\text { GDM diagnosed on } \\
\text { basis of OGTT } \\
\text { according to } \\
\text { Carpenter and } \\
\text { Coustan }\end{array}$ & $\begin{array}{l}\text { 16-18: } \\
6.6 \% \text { [5.2- } \\
8.1 \\
24-26: \\
5.8 \%[4.4- \\
7.2] \\
30-32: \\
9.9 \%[8.1- \\
11.6] \\
\text { Total: } 22.4 \\
\text { [19.9-24.9] }\end{array}$ & 1 \\
\hline $\begin{array}{l}\text { Orecchio, } \\
\text { Switzerland, } \\
2004-2005\end{array}$ & $\begin{array}{l}\text { Prospective } \\
\text { study of all } \\
\text { singleton } \\
\text { pregnant } \\
\text { women at } \\
\text { one } \\
\text { hospital }\end{array}$ & 1,042 & NR & NR & NR & NR & $\begin{array}{l}\text { Two step: } \\
\text { those with } \\
\text { positive } \\
\text { GCT } \\
\text { given } \\
\text { 100g } \\
\text { OGTT }\end{array}$ & $24-28$ & $\begin{array}{l}\text { GCT of } 7.8 \mathrm{mmol} / 1 \\
\text { or more positive. } \\
\text { GDM diagnosed on } \\
\text { basis of OGTT } \\
\text { according to } \\
\text { Carpenter and } \\
\text { Coustan }\end{array}$ & $\begin{array}{l}4.8 \%[3.5- \\
6.1]\end{array}$ & 1 \\
\hline Oriot, & Retrospecti & 1,424 & NR & NR & NR & NR & Two step: & $24-28$ & GCT of $7.8 \mathrm{mmol} / 1$ & $8.2 \%[6.8-$ & 2 \\
\hline
\end{tabular}




\begin{tabular}{|c|c|c|c|c|c|c|c|c|c|c|c|}
\hline $\begin{array}{l}\text { First author, } \\
\text { country, } \\
\text { years data } \\
\text { collected }\end{array}$ & $\begin{array}{l}\text { Sampling } \\
\text { Method add } \\
\text { if singleton } \\
\text { or twin }\end{array}$ & $\begin{array}{l}\text { Sample } \\
\text { Size }\end{array}$ & $\begin{array}{l}\text { Mean } \\
\text { Age } \\
{[\mathrm{SD}]}\end{array}$ & $\begin{array}{l}\text { Mean } \\
\text { BMI } \\
{[S D]}\end{array}$ & $\begin{array}{l}\text { Parity [\% } \\
\text { nulli- } \\
\text { parous] }\end{array}$ & $\begin{array}{l}\text { Family } \\
\text { History }\end{array}$ & $\begin{array}{l}\text { Screening } \\
\text { Type }\end{array}$ & $\begin{array}{l}\text { Gestation } \\
\text { at testing } \\
\text { [weeks] }\end{array}$ & $\begin{array}{l}\text { Criteria Used } \\
\text { [category] }\end{array}$ & $\begin{array}{l}\text { Overall } \\
\text { prevalence } \\
{[95 \% \mathrm{CI}]}\end{array}$ & $\begin{array}{l}\text { Quality } \\
\text { Score }\end{array}$ \\
\hline $\begin{array}{l}\text { Belgium, } \\
2009-2011, \\
\text { cohort } 1\end{array}$ & $\begin{array}{l}\text { ve study of } \\
\text { all pregnant } \\
\text { women at } \\
\text { one } \\
\text { hospital }\end{array}$ & & & & & & $\begin{array}{l}\text { those with } \\
\text { positive } \\
\text { GCT } \\
\text { given } \\
\text { 100g } \\
\text { OGTT. } \\
\end{array}$ & & $\begin{array}{l}\text { or more positive. } \\
\text { GDM diagnosed on } \\
\text { basis of OGTT } \\
\text { according to } \\
\text { Carpenter and } \\
\text { Coustan } \\
\end{array}$ & $9.6]$ & \\
\hline $\begin{array}{l}\text { Oriot, } \\
\text { Belgium, } \\
2011-2012, \\
\text { cohort } 2\end{array}$ & $\begin{array}{l}\text { Retrospecti } \\
\text { ve study of } \\
\text { all pregnant } \\
\text { women at } \\
\text { one } \\
\text { hospital }\end{array}$ & 1,206 & NR & NR & NR & NR & $\begin{array}{l}\text { One step: } \\
75 \mathrm{~g} \\
\text { OGTT }\end{array}$ & $24-28$ & $\begin{array}{l}\text { GDM diagnosed } \\
\text { according to } \\
\text { IADPSG }\end{array}$ & $\begin{array}{l}22.9 \% \\
{[20.5-25.3]}\end{array}$ & 2 \\
\hline $\begin{array}{l}\text { Östlund, } \\
\text { Sweden, } \\
1994-1996\end{array}$ & $\begin{array}{l}\text { Prospective } \\
\text { study of all } \\
\text { pregnant } \\
\text { women in } \\
\text { one area }\end{array}$ & 3,616 & $\begin{array}{l}27.9 \\
{[4.8]}\end{array}$ & $\begin{array}{l}23.8 \\
{[4.1]}\end{array}$ & $46 \%$ & $9.4 \%$ & $\begin{array}{l}\text { One step: } \\
75 \mathrm{~g} \\
\text { OGTT }\end{array}$ & $28-32$ & $\begin{array}{l}\text { GDM diagnosed } \\
\text { according to } \\
\text { IADPSG }\end{array}$ & $\begin{array}{l}1.7 \%[1.3- \\
2.1]\end{array}$ & 1 \\
\hline $\begin{array}{l}\text { Pérez-Ferre, } \\
\text { Spain, 2007- } \\
2008\end{array}$ & $\begin{array}{l}\text { Retrospecti } \\
\text { ve study of } \\
\text { all pregnant } \\
\text { women in } \\
\text { one area }\end{array}$ & 1,311 & NR & NR & NR & NR & $\begin{array}{l}\text { Two step: } \\
\text { those with } \\
\text { positive } \\
\text { GCT } \\
\text { given } \\
\text { 100g } \\
\text { OGTT. } \\
\text { Carbohyd } \\
\text { rate rich } \\
\text { diet } \\
\text { followed }\end{array}$ & $24-28$ & $\begin{array}{l}\text { GCT of } 7.8 \mathrm{mmol} / 1 \\
\text { or more positive. } \\
\text { GDM diagnosed on } \\
\text { basis of OGTT } \\
\text { according to } \\
\text { Carpenter and } \\
\text { Coustan }\end{array}$ & $\begin{array}{l}5.4 \%[4.5- \\
7]\end{array}$ & 1 \\
\hline
\end{tabular}




\begin{tabular}{|c|c|c|c|c|c|c|c|c|c|c|c|}
\hline $\begin{array}{l}\text { First author, } \\
\text { country, } \\
\text { years data } \\
\text { collected }\end{array}$ & $\begin{array}{l}\text { Sampling } \\
\text { Method add } \\
\text { if singleton } \\
\text { or twin }\end{array}$ & $\begin{array}{l}\text { Sample } \\
\text { Size }\end{array}$ & $\begin{array}{l}\text { Mean } \\
\text { Age } \\
{[\mathrm{SD}]}\end{array}$ & $\begin{array}{l}\text { Mean } \\
\text { BMI } \\
{[\mathrm{SD}]}\end{array}$ & $\begin{array}{l}\text { Parity [\% } \\
\text { nulli- } \\
\text { parous] }\end{array}$ & $\begin{array}{l}\text { Family } \\
\text { History }\end{array}$ & $\begin{array}{l}\text { Screening } \\
\text { Type }\end{array}$ & $\begin{array}{l}\text { Gestation } \\
\text { at testing } \\
\text { [weeks] }\end{array}$ & $\begin{array}{l}\text { Criteria Used } \\
\text { [category] }\end{array}$ & $\begin{array}{l}\text { Overall } \\
\text { prevalence } \\
{[95 \% \mathrm{CI}]}\end{array}$ & $\begin{array}{l}\text { Quality } \\
\text { Score }\end{array}$ \\
\hline & & & & & & & $\begin{array}{l}3 \text { days } \\
\text { prior to } \\
\text { OGTT. }\end{array}$ & & & & \\
\hline $\begin{array}{l}\text { Pintaudi, } \\
\text { Italy, 2010- } \\
2011\end{array}$ & $\begin{array}{l}\text { Retrospecti } \\
\text { ve study of } \\
\text { all pregnant } \\
\text { women at } \\
\text { one clinic }\end{array}$ & 1,015 & NR & NR & NR & NR & $\begin{array}{l}\text { One step: } \\
75 \mathrm{~g} \\
\text { OGTT }\end{array}$ & $24-28$ & $\begin{array}{l}\text { GDM diagnosed } \\
\text { according to } \\
\text { IADPSG }\end{array}$ & $11.1 \%$ & 1 \\
\hline $\begin{array}{l}\text { Pöyhönen- } \\
\text { Alho, } \\
\text { Finland, } \\
\text { 1996-1998 }\end{array}$ & $\begin{array}{l}\text { Prospective } \\
\text { study of } \\
\text { pregnant } \\
\text { women } \\
\text { from one } \\
\text { area }\end{array}$ & 532 & NR & NR & NR & NR & $\begin{array}{l}\text { Two step: } \\
\text { those with } \\
\text { positive } \\
\text { GCT } \\
\text { given } \\
\text { 100g } \\
\text { OGTT. }\end{array}$ & 28 & $\begin{array}{l}\text { GCT of } 7.3 \mathrm{mmol} / 1 \\
\text { or more positive. } \\
\text { GDM diagnosed on } \\
\text { basis of OGTT with } \\
\text { fasting values of } \\
4.8 \mathrm{mmol} / 1 \text { or more, } \\
10 \mathrm{mmol} / 1 \text { or more } \\
\text { at } 1 \text { hour or } \\
8.7 \mathrm{mmol} / 1 \text { or more } \\
\text { at } 2 \text { hour. }\end{array}$ & $\begin{array}{l}2.8 \%[1.4- \\
4.2]\end{array}$ & 3 \\
\hline $\begin{array}{l}\text { Ricart, } \\
\text { Spain, } 2002\end{array}$ & $\begin{array}{l}\text { Prospective } \\
\text { study of all } \\
\text { singleton } \\
\text { pregnant } \\
\text { women } \\
\text { from } 16 \\
\text { hospitals }\end{array}$ & 9,270 & NR & NR & NR & NR & $\begin{array}{l}\text { Two step: } \\
\text { those with } \\
\text { positive } \\
\text { GCT } \\
\text { given } \\
\text { 100g } \\
\text { OGTT. }\end{array}$ & $24-28$ & $\begin{array}{l}\text { GCT of } 7.8 \mathrm{mmol} / 1 \\
\text { or more positive. } \\
\text { GDM diagnosed on } \\
\text { basis of OGTT } \\
\text { according to } \\
\text { NDDG }\end{array}$ & $\begin{array}{l}8.8 \%[8.3- \\
9.4]\end{array}$ & 1 \\
\hline $\begin{array}{l}\text { Rüetschi, } \\
\text { Italy, 2010- } \\
2012\end{array}$ & $\begin{array}{l}\text { Retrospecti } \\
\text { ve study of } \\
\text { all pregnant } \\
\text { women in }\end{array}$ & 2,298 & 31 & NR & NR & NR & $\begin{array}{l}\text { One step: } \\
75 \mathrm{~g} \\
\text { OGTT }\end{array}$ & $24-28$ & $\begin{array}{l}\text { GDM diagnosed } \\
\text { according to } \\
\text { IADPSG }\end{array}$ & $\begin{array}{l}10.9 \% \text { [9.7- } \\
12.3]\end{array}$ & 1 \\
\hline
\end{tabular}




\begin{tabular}{|c|c|c|c|c|c|c|c|c|c|c|c|}
\hline $\begin{array}{l}\text { First author, } \\
\text { country, } \\
\text { years data } \\
\text { collected }\end{array}$ & $\begin{array}{l}\text { Sampling } \\
\text { Method add } \\
\text { if singleton } \\
\text { or twin }\end{array}$ & $\begin{array}{l}\text { Sample } \\
\text { Size }\end{array}$ & $\begin{array}{l}\text { Mean } \\
\text { Age } \\
{[\mathrm{SD}]}\end{array}$ & $\begin{array}{l}\text { Mean } \\
\text { BMI } \\
{[\mathrm{SD}]}\end{array}$ & $\begin{array}{l}\text { Parity [\% } \\
\text { nulli- } \\
\text { parous] }\end{array}$ & $\begin{array}{l}\text { Family } \\
\text { History }\end{array}$ & $\begin{array}{l}\text { Screening } \\
\text { Type }\end{array}$ & $\begin{array}{l}\text { Gestation } \\
\text { at testing } \\
\text { [weeks] }\end{array}$ & $\begin{array}{l}\text { Criteria Used } \\
\text { [category] }\end{array}$ & $\begin{array}{l}\text { Overall } \\
\text { prevalence } \\
{[95 \% \mathrm{CI}]}\end{array}$ & $\begin{array}{l}\text { Quality } \\
\text { Score }\end{array}$ \\
\hline & $\begin{array}{l}\text { with OGTT } \\
\text { data in } \\
\text { laboratories } \\
\text { in two } \\
\text { areas }\end{array}$ & & & & & & & & & & \\
\hline $\begin{array}{l}\text { Sacks, UK, } \\
\text { 2000-2006, }\end{array}$ & $\begin{array}{l}\text { Prospective } \\
\text { study of all } \\
\text { pregnant } \\
\text { women at } \\
\text { two study } \\
\text { centres }\end{array}$ & 1671 & NR & NR & NR & NR & $\begin{array}{l}\text { One step: } \\
75 \mathrm{~g} \\
\text { OGTT }\end{array}$ & $24-32$ & $\begin{array}{l}\text { GDM diagnosed } \\
\text { according to } \\
\text { IADPSG }\end{array}$ & $\begin{array}{l}21.3 \% \\
{[20.1-22.6]}\end{array}$ & 3 \\
\hline $\begin{array}{l}\text { Vassilaki, } \\
\text { Greece, } \\
2007\end{array}$ & $\begin{array}{l}\text { Prospective } \\
\text { study of } \\
\text { singleton } \\
\text { pregnant } \\
\text { women } \\
\text { from four } \\
\text { clinics in } \\
\text { one area } \\
\end{array}$ & 1,122 & NR & NR & NR & NR & $\begin{array}{l}\text { One step: } \\
75 \mathrm{~g} \\
\text { OGTT }\end{array}$ & $24-28$ & $\begin{array}{l}\text { GDM diagnosed } \\
\text { according to } \\
\text { Carpenter and } \\
\text { Coustan }\end{array}$ & $\begin{array}{l}9.1 \%[7.4- \\
10.8]\end{array}$ & 2 \\
\hline $\begin{array}{l}\text { Vignoles, } \\
\text { France, } \\
2006-2007\end{array}$ & $\begin{array}{l}\text { Retrospecti } \\
\text { ve study of } \\
\text { all } \\
\text { singleton } \\
\text { pregnant } \\
\text { women at } \\
\text { one } \\
\text { hospital } \\
\end{array}$ & 3,237 & NR & NR & NR & NR & $\begin{array}{l}\text { Two step: } \\
\text { those with } \\
\text { positive } \\
\text { GCT } \\
\text { given } \\
\text { 100g } \\
\text { OGTT. }\end{array}$ & $34-32$ & $\begin{array}{l}\text { GCT of } 7.2 \mathrm{mmol} / 1 \\
\text { or more positive. } \\
\text { GDM diagnosed on } \\
\text { basis of OGTT } \\
\text { according to } \\
\text { Carpenter and } \\
\text { Coustan }\end{array}$ & $\begin{array}{l}5.1 \%[4.4- \\
5.9]\end{array}$ & 1 \\
\hline
\end{tabular}


Table 2 Mean prevalence of GDM by several moderator variables

\begin{tabular}{|c|c|c|c|c|c|c|c|}
\hline Variable & $\mathbf{k}$ & $\mathbf{n}$ & Prevalence & $\begin{array}{l}95 \% \\
\text { CI }\end{array}$ & $Q_{\text {B }}[\mathbf{d f}]$ & $\mathbf{Q}_{w}[\mathbf{d f}]$ & $\begin{array}{l}\mathbf{I}^{2} \\
{[\%]}\end{array}$ \\
\hline \multicolumn{8}{|l|}{ Mean age [years] } \\
\hline 30.7 and below & 9 & 122,648 & $4.3 \%$ & $\begin{array}{l}2.3- \\
8.0\end{array}$ & $4.75[1]^{*}$ & $2312.38[8]^{*}$ & 99.7 \\
\hline 30.8 and above & 9 & 43,327 & $9.6 \%$ & $\begin{array}{l}6.7- \\
13.7\end{array}$ & & $806.49[8]^{*}$ & 99 \\
\hline \multicolumn{8}{|l|}{ Diagnostic Criteria } \\
\hline NDDG & 4 & 11,927 & $5.3 \%$ & $\begin{array}{l}2.7- \\
10\end{array}$ & $60.1[3]^{*}$ & $79.13[3]^{*}$ & 96.2 \\
\hline Carpenter Coustan & 15 & 47,502 & $6.9 \%$ & $\begin{array}{l}5.4- \\
8.7\end{array}$ & & $621.28[14]^{*}$ & 97.7 \\
\hline EASD 2 hour only & 4 & 299,153 & $1.4 \%$ & $\begin{array}{l}0.9- \\
2.2\end{array}$ & & $420.48[3]^{*}$ & 99.3 \\
\hline IADPSG & 10 & 46,557 & $14.1 \%$ & $\begin{array}{l}8.9- \\
21.5\end{array}$ & & $2275.49[9]^{*}$ & 99.6 \\
\hline \multicolumn{8}{|l|}{ Quality Category } \\
\hline 1 - Higher & 24 & 325,888 & $6.0 \%$ & $\begin{array}{l}4.1- \\
8.5\end{array}$ & $3.0[2]$ & $7999.56[21]^{*}$ & 99.7 \\
\hline 2 & 12 & $1,442,4833$ & $3.9 \%$ & $\begin{array}{l}2.2- \\
7.1\end{array}$ & & $6869.37[11]^{*}$ & 99.8 \\
\hline 3 - Lower & 6 & 13,895 & $7.6 \%$ & $\begin{array}{l}4.8- \\
12.0\end{array}$ & & $366.60[5]^{*}$ & 98.6 \\
\hline \multicolumn{8}{|l|}{ Country } \\
\hline Austria & 1 & 2,421 & $8.6 \%$ & $\begin{array}{l}7.5- \\
9.8\end{array}$ & $\begin{array}{l}101.96 \\
{[10]^{*}}\end{array}$ & $0.00[0]$ & 0.0 \\
\hline Belgium & 3 & 2,497 & $9 \%$ & $\begin{array}{l}3.3- \\
22.2\end{array}$ & & $133.24[2]^{*}$ & 98.5 \\
\hline Finland & 1 & 532 & $2.8 \%$ & $\begin{array}{l}1.7- \\
4.6\end{array}$ & & $0.00[0]$ & 0.0 \\
\hline France & 4 & 19,080 & $8 \%$ & $\begin{array}{l}4.1- \\
14.9\end{array}$ & & $403.18[3]^{*}$ & 99.26 \\
\hline Greece & 1 & 1,122 & $9.1 \%$ & $\begin{array}{l}7.5- \\
10.9\end{array}$ & & $0.00[0]$ & 0.0 \\
\hline Ireland & 2 & 6,799 & $5.9 \%$ & $\begin{array}{l}1.3- \\
23.8\end{array}$ & & $85.59[1] *$ & 9.8 \\
\hline Italy & 9 & 13,486 & $10 \%$ & $\begin{array}{l}7.6- \\
13\end{array}$ & & $210.45[8]^{*}$ & 96.2 \\
\hline Spain & 8 & 34,031 & $8.6 \%$ & $\begin{array}{l}5.1- \\
14.1\end{array}$ & & $1259.12[7]^{*}$ & 99.4 \\
\hline
\end{tabular}




\begin{tabular}{|c|c|c|c|c|c|c|c|}
\hline Sweden & 7 & $1,663,514$ & $1.5 \%$ & $1-2.3$ & & $3335.68[6]^{*}$ & 99.8 \\
\hline Switzerland & 1 & 1042 & $4.8 \%$ & $\begin{array}{l}3.7- \\
6.3\end{array}$ & & $0.00[0]$ & 0.0 \\
\hline UK & 5 & 37,292 & $2.4 \%$ & $\begin{array}{l}0.8- \\
7.0\end{array}$ & & $1519.62[4] *$ & 99.7 \\
\hline \multicolumn{8}{|l|}{ Area of Europe } \\
\hline Northern & 15 & $1,708,137$ & $2.3 \%$ & $\begin{array}{l}1.3- \\
3.8\end{array}$ & $\begin{array}{l}24.32[2] \\
*\end{array}$ & $14880.94[14]^{*}$ & 99.9 \\
\hline Western & 9 & 26,346 & $7.3 \%$ & $\begin{array}{l}4.6- \\
11.3\end{array}$ & & $651.79[8]^{*}$ & 98.8 \\
\hline Southern & 18 & 47,783 & $9.6 \%$ & $\begin{array}{l}7.3- \\
12.6\end{array}$ & & $1530.48[17] *$ & 98.9 \\
\hline \multicolumn{8}{|l|}{$\begin{array}{l}\text { Year data collection } \\
\text { started }\end{array}$} \\
\hline 1980-1989 & 2 & 2,824 & $0.9 \%$ & $\begin{array}{l}0.1- \\
10\end{array}$ & $\begin{array}{l}14.95[3] \\
*\end{array}$ & $27.77[1] *$ & 96.4 \\
\hline 1990-1999 & 14 & $1,508,604$ & $2.9 \%$ & $\begin{array}{l}1.9- \\
4.5\end{array}$ & & $5500.94[13] *$ & 99.8 \\
\hline 2000-2009 & 13 & 233,199 & $6.9 \%$ & $\begin{array}{l}4.3- \\
10.8\end{array}$ & & $5434.77[12] *$ & 99.8 \\
\hline 2010-2016 & 9 & 34,343 & $11.1 \%$ & $\begin{array}{l}5.7- \\
20.6\end{array}$ & & $2187.66[8] *$ & 99.6 \\
\hline \multicolumn{8}{|l|}{$\begin{array}{l}\text { \% sample with } \\
\text { family history of } \\
\text { diabetes }\end{array}$} \\
\hline $14 \%$ and below & 5 & 10,106 & $12 \%$ & $\begin{array}{l}5.2- \\
25.3\end{array}$ & $0.971[1]$ & $804.53[4] *$ & 99.5 \\
\hline $15 \%$ and over & 3 & 9,989 & $7.6 \%$ & $\begin{array}{l}4.9- \\
11.5\end{array}$ & & $65.3[2] *$ & 96.9 \\
\hline \multicolumn{8}{|l|}{ \% sample Caucasian } \\
\hline $79 \%$ and below & 2 & 3,276 & $20.3 \%$ & $\begin{array}{l}5.4- \\
53.6\end{array}$ & $2.73[1]$ & $265.93[1] *$ & 99.6 \\
\hline $80 \%$ and over & 7 & 102,821 & $5.5 \%$ & $\begin{array}{l}2.4- \\
12.3\end{array}$ & & $3040.83[6] *$ & 99.8 \\
\hline \multicolumn{8}{|l|}{ Gestation at testing } \\
\hline 24-28 weeks & 28 & 105,096 & $7.5 \%$ & $\begin{array}{l}5.9- \\
9.4\end{array}$ & $\begin{array}{l}104.85 \\
{[3] *}\end{array}$ & $2841.69[27] *$ & 99.1 \\
\hline 28 weeks & 6 & 381,273 & $1.9 \%$ & $\begin{array}{l}1.5- \\
2.5\end{array}$ & & $449.79[5] *$ & 98.9 \\
\hline 28-32 weeks & 1 & 3,616 & $1.7 \%$ & $\begin{array}{l}1.3- \\
2.2\end{array}$ & & $0.00[0]$ & 0.0 \\
\hline Multiple time points & 4 & 8,877 & $13.1 \%$ & $\begin{array}{l}6.5- \\
24.7\end{array}$ & & $367.84[3] *$ & 99.2 \\
\hline
\end{tabular}




\begin{tabular}{|lllllllll}
\hline Mean BMI & & & & & & & & \\
$20-24.9$ & 10 & 19,131 & $9.8 \%$ & $\begin{array}{l}5.5- \\
16.9\end{array}$ & $0.39[1]$ & $1062.55[7] *$ & 99.3 \\
& $25-29.9$ & 2 & 6,799 & $5.9 \%$ & $\begin{array}{l}1.3- \\
23.8\end{array}$ & $85.59[1] *$ & 98.8 \\
& & & & & & \\
\end{tabular}

* $\mathrm{p}<0.05 ; \mathrm{k}$ : number of studies; $\mathrm{n}$ : total sample size; $\mathrm{Q}_{\mathrm{B}}$ : between study homogeneity statistic; $\mathrm{Q}_{\mathrm{W}}$ : within study homogeneity statistic; $\mathrm{I}^{2}$ proportion of variability within categories due to heterogeneity rather than sampling error. 
Table 3 Weighted multiple regression for GDM prevalence

\begin{tabular}{|c|c|c|c|}
\hline & $\beta$ & $95 \% \mathrm{CI}$ & $Q_{[B]}[d f]$ \\
\hline \multicolumn{4}{|l|}{ Quality Category } \\
\hline 1 - Higher & - & - & $14.85[2] *$ \\
\hline 2 & 0.042 & $-0.35-0.44$ & \\
\hline 3 - Lower & $0.97 *$ & $0.47-1.47$ & \\
\hline \multicolumn{4}{|l|}{ Area of Europe } \\
\hline North & - & - & $18.07[2] *$ \\
\hline West & $0.54 *$ & $0.02-1.06$ & \\
\hline South & $1.04 *$ & $0.54-1.53$ & \\
\hline \multicolumn{4}{|c|}{ Year data collection started } \\
\hline 1980-1989 & - & - & $29.03[3] *$ \\
\hline 1990-1999 & $1.85^{*}$ & $0.71-3.0$ & \\
\hline 2000-2009 & $2.37 *$ & $1.21-3.52$ & \\
\hline 2010-2016 & $2.74 *$ & $1.61-3.88$ & \\
\hline \multicolumn{4}{|l|}{ Gestation at testing } \\
\hline 24-28 weeks & 0.49 & $-0.54-1.52$ & $9.58[3]^{*}$ \\
\hline 28 weeks & -0.15 & $-1.11-0.83$ & \\
\hline 28-32 weeks & - & - & \\
\hline Multiple time points & 1.03 & $-0.11-2.17$ & \\
\hline \multicolumn{4}{|l|}{ Type of Screening } \\
\hline One step & - & - & \\
\hline Two step & $-0.41 *$ & $-0.77-0.04$ & \\
\hline
\end{tabular}

* $\mathrm{p}<0.05 ; \mathrm{Q}_{\mathrm{B}}$ : between study homogeneity statistic; 